Wiktor Hołubko

Lwowski Narodowy Uniwersytet im. Iwana Franki e-mail: vholubko@yahoo.com telefon: +380 238-43-90

Adam Lityński

Wyższa Szkoła Humanitas w Sosnowcu e-mail: adamlityn@interia.pl telefon: 32 258-09-07

DOI: $10.15290 / \mathrm{mhi} .2017 .16 .01 .01$

\title{
Ukraina na drodze do niepodległości (1918-1920) W setną rocznicę
}

\author{
SUMMARY \\ Ukraine on the way to independence (1918-1920). 100th anniversary
}

After the 1917 revolution in Russia, the Ukrainians began their struggle for independence. They created the state's authorities and in January 1918, proclaimed independence. Ukraine at that time was occupied both by German and Austro-Hungarian troops. The Ukrainian authorities signed a tripartite agreement with Germany and the Austro-Hungarian Empire to protect the newborn state from the Bolshevik Russian government. In exchange, the Ukrainians undertook to supply the Germans and Austro-Hungarians with food produce. World War I ended in the defeat of Germany and the Austro-Hungarians, and Ukraine was subsequently treated by the Entente states as an ally. There were two coup d'etats in the Ukrainian authorities. Following the end of WWI, Ukraine found itself at war with Bolshevik Russia, and later with Poland on its western border. After sustaining heavy losses against the Bolsheviks, in 1920 Ukraine signed a pact with Poland to join forces in the fight together against Russia. However, it was too late to save the country's independence. Ukraine became part of Soviet Union until 1991.

Key words: 1917 revolution, Russia, Ukraine, independence, wars. rewolucja 1917, Rosja, Ukraina, niepodległość, wojny.

\section{Tworzenie podstaw republiki parlamentarnej}

Kiedy w marcu (lutym) 1917 r. imperium Romanowych padło obalone rewolucją, Ukraińcy żyjący pod rosyjskim panowaniem stanowili najliczniejszy naród na wschodzie Europy (ok. $30 \mathrm{mln}$ ), ale przez carat za odrębny naród nie 
byli uważani. Od czasu likwidacji w drugiej połowie XVIII w. odrębności Ukrainy, podzielenia jej na dziewięć guberni rosyjskich i poddania prawu imperialnemu, tradycja państwowości ukraińskiej żyła w pamięci społeczeństwa jako relikt historyczny, stając się częścią świadomości narodowej. Jak wiadomo, ruch narodowy na Ukrainie na wydarzenia w Piotrogrodzie zareagował nad wyraz szybko, bo już 4(17) marca 1917 r. w Kijowie powstała pierwsza ogólnokrajowa instytucja - Ukraińska Centralna Rada (UCR), reprezentująca różne ukraińskie stronnictwa polityczne, organizację społeczne i kulturalne. 10(23) czerwca UCR proklamowała, bez uzgodnienia z Piotrogrodem, w I Uniwersale autonomię Ukrainy. Jednocześnie utworzyła organ wykonawczy - Sekretariat Generalny, z odpowiednimi resortami, a więc pełniący rolę rządu; Sekretariat ponosił odpowiedzialność polityczną przed UCR. Do 30 czerwca (13 lipca) 1917 r., kiedy to podpisano ugodę między UCR a rosyjskim Rządem Tymczasowym, UCR przez rząd w Piotrogrodzie nie była uznawana za instytucję reprezentującą Ukrainę. Mocno drażliwą sprawą była w szczególności kwestia granic terytorialnych autonomii ukraińskiej. Po zamachu bolszewickim 25 października (7 listopada) 1917 r. i upadku Rządu Tymczasowego, w warunkach chaosu politycznego oraz imperialnych tendencji bolszewików, UCR w swoim III Uniwersale proklamowała (4/17 listopada 1917 r.) Ukraińską Republikę Ludową (URL) w związku federacyjnym z Rosją, lecz nie bolszewicką. Dzień wcześniej (3/16 listopada 1917 r.) rząd Centralnej Rady w swojej deklaracji pod tytułem Od Generalnego Sekretariatu Ukrainy podporządkował sobie wszystkie agendy byłego rządu rosyjskiego na Ukrainie i tym samym oznajmił, że jest najwyższą władzą wykonawczą w kraju i żąda wykonywania jego rozporządzeń ${ }^{1}$. Zgodnie z Uniwersałem URL miała obejmować ziemie zamieszkane $w$ większości przez Ukraińców ${ }^{2}$. Ten właśnie problem - terytorium mającego powstać państwa ukraińskiego - dotychczas niemal się nie pojawiał w poczynaniach, oświadczeniach i dokumentach działaczy narodowych. Pojawił się natomiast w związku ze wspomnianą wcześniej ugodą między UCR a Rządem Tymczasowym, w wyniku której UCR uzyskiwała status przedstawicielki rządu w pięciu guberniach: kijowskiej, podolskiej, połtawskiej, wołyńskiej i części czernihowskiej ${ }^{3}$. Wielce to było odległe od oczekiwań Ukraińców: nie było tu ani Charkowa, ani Donbasu, ani Krzywego Rogu. Tego Rząd Tymczasowy w Piotrogrodzie Ukraińcom „nie dał”. Nadto, zostawały jeszcze co najmniej dwa duże pytania dotyczące terytorium przyszłej Ukrainy: co z kozackim Wojskiem Dońskim (zob. niżej); co z Ukraińcami w Galicji Wschodniej w tym momencie pod

1 П. Христюк, Замітки і матеріяли до історії української революиї̈ 1917-1920, t. 2, Відень 1921, s. $50-51$.

2 Ibidem, t. 2, s. 51; W. Serczyk, Historia Ukrainy, wyd. 4, Wrocław 2009, s. 260.

3 М. Грушевський, Україна і Росія. Переговори в справі нового ладу (липень - серпень 1917 р.), [w:] Хто такі україниі і иого вони хочуть?, Київ 1991, s. 33. 
panowaniem austriackim, do której to Galicji zgłaszała roszczenia strona polska. Zwłaszcza ta druga sprawa stała się sprawą krwawą na następnych lat kilkadziesiąt. Były to zagadnienia nie tylko nierozstrzygnięte, ale szczególnie zawikłane pod każdym względem: narodowościowym, splotem wydarzeń na froncie wojny światowej, granicami mocarstw walczących, wreszcie sytuacją polityczną w wojującej Europie, krańcowo zmienną w ciągu miesięcy od listopada 1917 r. do listopada 1918 r. Wybiegając nieco tylko w przód w chronologicznej relacji, warto przypomnieć, że podczas separatystycznych rokowań pokojowych w Brześciu (luty 1918 r.) pojawiły się dwie delegacje ukraińskie: jedna reprezentująca siły radzieckie, druga Ukraińskiej Centralnej Rady. Do obrad odbywanych niemal pod dyktando Niemiec - dopuszczona została tylko UCR i tylko Ukraińska Republika Ludowa została uznana przez państwa centralne. Ukraińska Centralna Rada zgłosiła żądania przyłączenia do Ukrainy Galicji Wschodniej, Bukowiny i Zakarpacia, co zostało odrzucone, bo były to ziemie niemieckiego sojusznika, ale w zamian za to przekazano Ukrainie (z którą podpisano odrębny traktat pokojowy) polskie ziemie należące w 1914 r. do Rosji, tj. Chełmszczyznę i Podlasie ${ }^{4}$.

Nie były to bynajmniej wszystkie problemy i pretensje terytorialne Ukraińskiej Republiki Ludowej i jej Centralnej Rady. Między innymi była sprawa Besarabii, czyli carskiej guberni besarabskiej, do której pretensje zgłaszała Rumunia. Besarabia ogłosiła się (2 grudnia 1917) Mołdawską Republiką Ludową ${ }^{5}$ pozostającą $\mathrm{w}$ federacyjnym związku z Rosją. Bolszewicy próbowali dokonać (13-15 stycznia 1918) rewolucyjnego przewrotu i opanować Kiszyniów, a wówczas Rada Krajowa Mołdawii zwróciła się o pomoc do Rumunii. Wojska rumuńskie rozprawiły się z bolszewikami i Rada Krajowa proklamowała (24 stycznia 1918) niepodległą Mołdawską Republikę Demokratyczną, chociaż trwały spory między zwolennikami pełnej samodzielności państwowej a zwolennikami przyłączenia do Rumunii z zachowaniem autonomii. Wówczas do części ziem Republiki Mołdawskiej zgłosiła (15 marca 1918) pretensje Ukraińska Centralna Rada. Rumunia, koalicjant Ententy, miała po wojnie otrzymać Besarabię jako rekompensatę za południową Dobrudżę. W końcu w Mołdawii zwyciężyła opcja pełnej integracji z Rumunią (grudzień 1918), co zostało uznane $\mathrm{w}$ traktacie pokojowym $\mathrm{z}$ Rumunią (7 maja 1918) i w Sèvres (10 sierpnia 1920) oraz co uznały państwa Ententy (19 maja 1922). Kiedy wspólnie z Armią Czerwoną podporządkowane jej dowództwu ukraińskie formacje radzieckie rozbiły białe Siły Zbrojne Południa Rosji (Denikina) i zajmowały Ukrainę tworząc rząd komunistyczny, wówczas (grudzień 1919) W. Lenin, zwracając się do robotników i chłopów Ukrainy zajmował

4 W. Serczyk, op. cit., s. 265.

5 Гражданская война и военная интервениия в СССР. Энииклопедия. Гл. ред. С. С. Хромов, Москва 1983, s. 354. 
stanowisko, że granice między Rosją a Ukrainą to kwestia w tym momencie nieważna, drugorzędna, „dążymy bowiem do zupełnego zniesienia granic państwowych"6. W 1920 r., kiedy Armia Czerwona szła na zachód, opanowała także ziemie na lewym brzegu Dniestru i już stamtąd nie wyszła. Ziemie te następnie przyłączono do Ukraińskiej Socjalistycznej Republiki Radzieckiej (USRR) tworząc (12 października 1924) Mołdawską Autonomiczną SRR w ramach USRR. Ciąg dalszy będzie miał miejsce w ramach realizacji paktu Ribbentrop-Mołotow. Poza dawną gubernią besarabską, warto jeszcze mieć w pamięci sprawę guberni taurydzkiej, czyli sprawę Krymu, oraz Zakarpacia. Ostatecznie Krym znalazł się w Rosji, zaś Ruś Zakarpacka w Czechosłowacji.

Wracając do wydarzeń z przełomu 1917 i 1918 r.: po proklamowaniu URL stosunki między Kijowem a rosyjskim rządem bolszewickim z dnia na dzień pogorszały się. Przyczyny leżały w płaszczyźnie tak ideologicznej, jak i narodowościowej. Ukraińscy socjaliści tworzący rząd URL - Sekretariat Generalny - spotkali się z nieznanym im dotąd zjawiskiem bolszewizmu. Sami byli przekonanymi demokratami i federalistami; wzięli na siebie misję utworzenia federalnego ogólnorosyjskiego rządu. Zamach stanu i utworzenie w Piotrogrodzie rządu bolszewików zmusił UCR do zajęcia stanowiska wobec nowych władz. Uczyniła to nie zwlekając. Na posiedzeniu Małej Rady 8 listopada 1917 r. przyjęto uchwałę, w której potępiono zamach bolszewicki z uzasadnieniem, że władza w państwie ma reprezentować wszystkie siły demokratyczne, a nie tylko ich część, którą są rady robotnicze i żołnierskie. Zapowiedziano, że wszelkie próby buntu na Ukrainie będą stłumione. Rząd bolszewików był bardzo zaniepokojony rokowaniami zmierzającymi do utworzenia ogólnorosyjskiego rządu federalnego, podjętymi przez rząd URL z innymi rządami powstałymi na terenach Rosji po zamachu bolszewickim. Oprócz Ukrainy największe kłopoty bolszewicy mieli z obwodami kozackimi, zwłaszcza z Kozakami Dońskimi.

W byłym imperium carów Kozacy liczyli ok. 4,5 mln osób, przy czym co najmniej ${ }^{7} 300$ tys. z nich walczyło w I wojnie światowej; tradycyjnie ludność kozacka trudniła się służbą wojskową. Kozacy mieli silne poczucie odrębności i wewnętrznej spójności (także między oficerami i prostymi żołnierzami). W czasach carskich na ogół cieszyli się przywilejami, m.in. mieli prawo tworzenia lokalnych samorządów. Ich najwyższą władzą samorządową był tzw. krąg

6 W. Lenin, List do robotników i chłopów Ukrainy z powodu zwycięstw nad Denikinem, [w:] idem, Dzieła wszystkie, t. 40, Warszawa 1988, s. 40, 43; toż w innych tłumaczeniach idem, Dzieła wybrane, t. 2, Warszawa 1949, s. 640, też s. 643; idem, Dzieła wybrane, t. 3, Warszawa 1978, s. 866, też s. 864.

7 Niektóre źródła podają liczbę 450 tys. żołnierzy kozackich w przededniu I wojny światowej. Wielka Encyklopedia Powszechna (dalej: WEP), XIV, Warszawa, s. 499. Fragmentarycznie wykorzystuję tutaj tekst A. Lityński, Rewolucji rosyjskiej rok pierwszy. Wybrane zagadnienia prawa karnego, [w:] Nil nisi veritas. Księga dedykowana Profesorowi Jackowi Matuszewskiemu, red. M. Głuszak, D. Wiśniewska-Jóźwiak, Łódź 2016, s. 481 i n. 
wojskowy (rada wojskowa), w którym mieli prawo uczestniczyć zdolni do noszenia broni lub $\mathrm{w}$ tym rzemiośle mający dawne zasługi; wybierali swojego atamana; mieli sąd $\mathrm{z}$ obieranymi sędziami. $\mathrm{W}$ rezultacie byli mniej podatni na hasła rewolucyjne. Słabością kozackich regionów było, że ich ludność nie była jednolita; znaczna część mieszkańców kozackich regionów nie była pochodzenia kozackiego i wśród niej hasła rewolucji zyskiwały posłuch, a antybolszewickie działania Kozaków spotykały się z oporem. W Polsce skojarzenie Kozaka łączy się powszechnie z Ukrainą i miewa rodowód Sienkiewiczowski. Trzeba jednak zdawać sobie sprawę, że Kozacy - rozmaitego zresztą pochodzenia etnicznego ${ }^{8}$ - mieli swoje siedziby od Ukrainy aż do Amuru.

Wiosną 1917 r., po rewolucji lutowej, wśród Kozaków w europejskiej części Rosji nastąpiło ożywienie polityczne; pojawiły się żądania dotyczące samorządu, autonomii, przekształcenia Rosji w państwo federacyjne $\mathrm{z}$ odpowiednimi awansami terytoriów („wojsk”, stanic) kozackich. Już w kwietniu 1917 r. liderzy Kozaków kubańskich na zgromadzeniu swojego najwyższego organu - kręgu wojskowego - zgłosili żądanie przekształcenia Rosji w państwo federacyjne ${ }^{9}$. W sierpniu $1917 \mathrm{r}$. takie samo żądanie przedłożyli władzom piotrogrodzkim Kozacy orenburscy ${ }^{10}$. We wrześniu tegoż roku konferencja przedstawicieli Kozaków dońskich, kubańskich i tereckich zagroziła, że wprowadzi w Rosji federację, nie oglądając się na zgodę, siłą. Podjęto wówczas decyzję o utworzeniu Południowo-Wschodniego Związku terytoriów kozackich ${ }^{11}$. Jeszcze pod koniec tego samego miesiąca (wrzesień 1917) na konferencji przedstawicieli Kozaków dońskich, kubańskich, tereckich, astrachańskich i górskich Kaukazu został przygotowany tekst umowy o ustanowieniu federacji regionalnej; dokument podpisano 20 października 1917 r. we Władykaukazie. Przewidziano $\mathrm{w}$ nim m.in. pomoc wzajemną regionów autonomicznych $\mathrm{w}$ sprawach politycznych i wojskowych (wojennych) oraz w kontaktach z władzami centralnymi. Jako najwyższy organ federacji kozackiej przewidziano zebranie przedstawicieli kozackich rządów związkowych, zaś jako najwyższy organ wykonawczy wspólny rząd [Обединенное правительство]. Kozacy orenburscy zgłosili akces do tej federacji. Zostały podjęte rozmowy z Ukraińską Centralną Radą $^{12} \mathrm{w}$ sprawie przystąpienia do związku państwowego z Ukrainą; rozma-

8 Między innymi: Kozacy dońscy w najdalszych swoich korzeniach etnicznych pochodzą od ludów tureckich, a elementy kultury turańskiej istniały jeszcze w połowie XIX w.; Kozacy kubańscy to przybysze z Zaporoża, znad Donu, Czerkiezi; Kozacy terscy [tereccy] to w części potomkowie Kabardyńców i Osetyjczyków, Czeczenów i Inguszy; Kozacy siemireccy [siemirieczeńscy] to m.in. potomkowie zesłanych hajdamaków, konfederatów barskich oraz jeńców napoleońskich. 
wiano także z Komitetem Zakaukaskim ${ }^{13}$. Bezpośrednio przed I wojną światową łącznie trzynaście regionów („,wojsk") kozackich miało bronić imperium; w XIX w. najważniejsze ${ }^{14}$ to kozackie wojska dońskie, wołżańskie, astrachańskie, orenburskie, siemireckie ${ }^{15}$, zabajkalskie, amurskie, ussuryjskie, później też kubańskie, tereckie ${ }^{16}$. Część była położona daleko od centrum i późniejszych ognisk rewolucyjnych; stanice na Syberii nie mogły zagrozić stolicy. Na bolszewicki zamach stanu najszybciej (26 października/8 listopada 1917 r.) zareagowali Kozacy - negatywnie.

Kozacy dońscy pod atamanem generałem Aleksym Kaledinem ${ }^{17}$, Kozacy orenburscy pod atamanem pułkownikiem Aleksandrem Dutowem, Kozacy zabajkalscy pod esaułem Grzegorzem Siemionowem, także duże stanice Kozaków kubańskich i tereckich - wszyscy oni natychmiast po otrzymaniu wieści o bolszewickim zamachu odmówili podporządkowania się nowym $\mathrm{w}$ stolicy kraju władzom. Zbrojnie szybko wystąpił ataman Dutow, a stanica orenburska - położona tam gdzie Europa styka się z Syberią i Azją Środkową - stała się niezwłocznie aktywnym ośrodkiem walki z siłami bolszewickimi. Dutow obalił radę w Orenburgu i przez jakiś czas rozszerzał teren swoich wpływów. Nie długo jednak. Nękały Dutowa oddziały zbolszewizowanych robotników wysyłane często z daleka w trybie „wojny eszelonowej”, a w końcu nie dał rady Północnej Lotnej Kolumnie wojsk bolszewickich; Orenburg został przez nich zdobyty (31 stycznia 1918 r.), a sam ataman z małą już garstką wiernych żołnierzy zepchnięty został na tereny południowego Uralu, a wiosną 1918 r. na stepy kazachskie $^{18}$. Za Uralem Kozacy nie stanowili takiej siły, jak nad Donem albo Kubaniem, ponieważ stanice były rozproszone i mniej liczne. Czwartą co do wielkości w Rosji była stanica zabajkalska i pod dowództwem młodego oficera kozackiego Grigorija Siemionowa ${ }^{19}$ odegrała rolę siły antybolszewickiej. Pano-

13 Carskim namiestnikiem Zakaukazia w 1917 r. był wielki książę Mikołaj Mikołajewicz (1856-1929), stryj cara Mikołaja II, generał, 1914-1915 naczelny wódz, zwolniony z tego stanowiska we wrześniu 1915 po klęsce pod Tannenbergiem, wówczas mianowany namiestnikiem Kaukazu oraz dowódcą frontu kaukaskiego; zrezygnował ze stanowisk po abdykacji cara. Po rewolucji lutowej w miejsce carskiego namiestnika dla całego Zakaukazia nowy rząd w Piotrogrodzie powołał (9/22 marca 1917 r.) w Tbilisi Specjalny Komitet Zakaukaski, złożony z kadetów, eserowców i mienszewików. Zob. m.in. WEP, XIV s. 499; J. Rohoziński, Bawetna, samowary i Sartowie. Muzulmańskie okrainy carskiej Rosji 1795-1916, Warszawa 2014, s. 589-591.

15 Nazwa pochodzi od Siedmiorzecza [Siemirieczje], krainy dzisiaj w płd.-wsch. Kazachstanie, na południe od jeziora Bałchasz i na płd.-zach. od jez. Ała-kol, na północ od miasta Ałma-Ata.

16 Kozacy terscy [tereccy] mieli siedziby na wschód od Kubania, nad rzeką Terek [Tieriek].

17 Aleksiej M. Kaledin (1861-1918), generał, podczas I wojny światowej dowódca korpusu i armii; w czerwcu 1917 wybrany atamanem kozackiego Wojska Dońskiego; po klęsce w walkach z bolszewikami popełnił samobójstwo. Leksykon historii świata: Rosja, red. W. Sienkiewicz, Warszawa 2001, s. 121.

E. Mawdsley, Wojna domowa w Rosji 1917-1920, tłum. M. Popławska, Warszawa 2010, s. 37. 
wanie nad takim gigantycznym obszarem jak Syberia, zależało bowiem przede wszystkim od panowania nad Koleją Transsyberyjską ${ }^{20}$. Ataman Siemionow zaś do października 1920 r. trzymał strategiczne miasto Czytę [Czitę], nieco na zachód od połączenia Kolei Transsyberyjskiej z Koleją Wschodniochińską ${ }^{21}$, a więc trzymał obie transkontynentalne linie kolejowe.

Najważniejszy był jednak obwód wojska dońskiego. Stanica dońska to obszar o powierzchni większej niż Anglia, zaś liczba tamtejszych Kozaków sięgała ponad 1,5 mln. Terytorium wojska dońskiego to była Europa i położenie było strategiczne: na obrzeżach Ukrainy i zagłębia węglowego Donbas, zaś największe miasta nad Donem - Nowoczerkask i Rostów leżały na szlaku kolejowym łączącym Rosję z Kaukazem. Istotne, że wybrany pół roku wcześniej ataman Aleksiej Kaledin miał duże doświadczenie wojskowe: wszak był generałem na froncie wojny światowej. To wojska kozackie znad Donu i Kubania będą wkrótce stanowiły główną siłę Armii Ochotniczej Denikina, który maszerując przez Ukrainę w kierunku Moskwy jakże bliski był zmianie biegu historii świata.

Kaledin już w dniu zwycięskiego dla bolszewików przewrotu ogłosił przejęcie przez nich władzy za przestępcze i w imieniu własnym oraz „w ścisłym powiązaniu z rządami pozostałych wojsk kozackich" zadeklarował pełne poparcie dla Rządu Tymczasowego. Stojący na czele Rządu Wojskowego Kaledin już 26 października (8 listopada) 1917 r. wystosował na ręce Kiereńskiego zaproszenie dla całego Rządu Tymczasowego do przybycia do Nowoczerkaska - stolicy Kozaków dońskich ${ }^{22}$. Tak szybka reakcja na zamach i kategoryczne stanowisko zyskały Kaledinowi rozgłos w całej Rosji. Wszak było to w tym momencie jedyne mogące się liczyć ognisko oporu wobec zwycięskich zamachowców w stolicy. Do Nowoczerkaska ściągali więc politycy i wojskowi

wików w stolicy przywódca antybolszewickiego powstania za Bajkałem, popierany przez Japonię; ogłosił się dyktatorem i atamanem Zabajkalskiego Wojska Kozackiego; faktyczny następca A. Kołczaka na Syberii; pokonany przez wojska Republiki Dalekiego Wschodu zamieszkał w Japonii i Chinach; 1945 ujęty przez NKWD w Mandżurii, skazany na śmierć i stracony. Leksykon historii świata: Rosja..., s. 233.

20 Transsyberyjska Kolej, Transsyberyjska Magistrala, Wielka Magistrala Syberyjska: jedna z najdłuższych na świecie linii kolejowych, łączy europejską część Rosji z Syberią i Dalekim Wschodem; zbudowana w latach 1895-1916; długość 9332 km nie licząc odgałęzień; biegnie z Moskwy przez Omsk, Irkuck, Chabarowsk do Władywostoku; dwutorowa; z odgałęzieniem do Mongolii i Chin; obecnie zelektryfikowana. WEP XXVII, s. 569; Leksykon historii świata: Rosja..., s. 264.

21 Kolei Wschodniochińskiej nie należy mylić z Koleją Transsyberyjską. Linia Kolei Wschodniochińskiej zbudowana została przez Rosję w latach 1897-1903. Przebiegała od granicy rosyjsko-chińskiej przez Mandżurię, Harbin (stąd nazwa od 1953 - Kolei Harbińska) i znowu przez granicę do Władywostoku. Na terenie Zabajkala łączyła się z Koleją Transsyberyjską. Linia była własnością Rosji i po 80 latach (w 1976) miała być przekazana Chinom. Po wojnie rosyjsko-japońskiej 1904-1905 część południowa (Kolej Południowomandżurska) znalazła się pod kontrolą Japonii aż do $1945 \mathrm{r}$. W 1945 przeszła pod zarząd radziecko-chiński, a w 1950 ZSRR odsprzedał Kolej Wschodniochińską rządowi Chin. WEP XIV, s. 124, też 123. 
wobec bolszewików opozycyjni, chociaż niekoniecznie o wspólnym zabarwieniu politycznym; najwięcej było tych z prawej strony sceny politycznej, czyli m.in. kadetów. Już w tydzień (2/15 listopada 1917 r.) po obaleniu Rządu Tymczasowego w Nowoczerkasku zjawił się generał Michał Aleksiejew, były wódz naczelny z okresu Rządu Tymczasowego, a wcześniej dowódca frontu i szef sztabu naczelnego wodza Mikołaja II. Nie bez obiekcji kozacki Rząd Wojskowy potwierdził stosowną decyzję o utworzeniu armii i zatwierdził nazwę Armia Ochotnicza. Jak wspominał generał Denikin, na propozycję Borysa Sawinkowa Armia Ochotnicza ogłosiła w deklaracji, iż celem jest zrzucenie jarzma "niemiecko-bolszewickiego" oraz zwołanie Zgromadzenia Ustawodawczego ${ }^{23}$. W kilka tygodni później (6/19 grudnia 1917) przybył do Nowoczerkaska generał Ławr Korniłow, także krótko były wódz naczelny z tygodni letnich Rządu Tymczasowego, słynny z nieudanego puczu i później drugiej już ucieczki z więzienia. Równie szybka była reakcja przewodniczącego Rady Komisarzy Ludowych (RKL) - Lenina, który napisał, a Rada Komisarzy Ludowych 28 listopada (11 grudnia) 1917 r. uchwaliła Dekret o aresztowaniu przywódców wojny domowej przeciw rewolucji ${ }^{24}$. Na rady delegatów w terenie nałożony został "obowiązek szczególnego nadzoru nad partią kadetów z powodu jej powiązania z korniłowsko-kaledinowską wojną domową przeciw rewolucji". To jeden z pierwszych aktów prawnych nowej władzy w Piotrogrodzie, który zawierał normy prawnokarne. Później jeszcze pojawi się dekret $\mathrm{O}$ walce $\mathrm{z}$ kontrrewolucyjnym powstaniem Kaljedina, Korniłowa, Dutowa i inne. Dokumenty te jednak bardziej przypominały odezwy polityczne aniżeli akty prawne, w szczególności nie zawierały żadnej nawet próby typizowania czynów zabronionych, zaś w zakresie środków karnych z reguły ograniczały się do sformułowania, że "podlega surowemu ukaraniu”"25.

\section{Rokowania brzeskie i ofensywy: sowiecka i niemiecka}

Konflikt który rozgorzał $\mathrm{w}$ sąsiedztwie Ukrainy, między kozackim obwodem dońskim a rządem bolszewickim, przyczynił się do wciągnięcia do niego URL. Bolszewicy żądali od strony ukraińskiej wstrzymania przechodu w kierunku Donu wojsk kozackich. Ukraińska Republika Ludowa zaś odmówiła motywując, że spowoduje to konflikt z Kozakami i oznajmiła, że zajmuje stanowisko neutralne. Jednak zachowanie neutralności okazało się niemożliwe, tak z powodu sytuacji geopolitycznej Ukrainy, która znalazła się pomiędzy wałczącymi $\mathrm{w}$ wojnie światowej stronami, jak i z powodu polityki rosyjskiego

Za: R. Pipes, Rosja bolszewików, tłum. W. Jeżewski, Warszawa 2005, s. 18. 
rządu bolszewików, który uzurpował sobie funkcje rządu federalnego. Na odpowiedź URL bolszewicy 4 (17) grudnia 1917 r. wysłali do Kijowa ultimatum, co w praktyce znaczyło wypowiedzenie wojny URL, ponieważ spełnienie jego warunków było nie do wykonania. Ukraina nie była przygotowana do wojny. Niemniej rząd URL odrzucił ultimatum bolszewickie. Rozpoczęła się tzw. pierwsza wojna ukraińsko-bolszewicka.

Dla zachowania chronologii wydarzeń warto $\mathrm{w}$ tym miejscu przypomnieć, że znajdująca się $\mathrm{w}$ beznadziejnym położeniu militarnym sowiecka Rosja 2(15) grudnia 1917 r. zawarła rozejm z Niemcami i podjęła w Brześciu Litewskim rozmowy na temat separatystycznego pokoju. Państwa centralne w Brześciu m.in. zażądały, by Rada Komisarzy Ludowych uznała prawo Centralnej Rady do reprezentowania Ukrainy w czasie rokowań brzeskich; będąc w sytuacji przymusowej RKL wyraziła taką zgodę ${ }^{26}$, a Rada Komisarzy Ludowych już 4(17) grudnia 1917 r. uznała niepodległość Ukrainy ${ }^{27}$. Obok uznania wszakże znalazło się $\mathrm{w}$ dokumencie wspomniane ultimatum, żądające w ciągu 48 godzin zadowalającej odpowiedzi w wymienionych sprawach ewidentnie naruszających niepodległość kraju: głównie chodziło o zaprzestanie pomocy Kaledinowi. W przeciwnym przypadku RKL uznaje, że znajduje się w stanie wojny z Ukrainą ${ }^{28}$. Jak stwierdza radziecki wydawca zbioru, dokument napisał Lenin ${ }^{29}$. Bolszewicy zawczasu nie zaniedbali zostawić sobie furtki: zjazdy SDPRR(b) w Charkowie ${ }^{30}$ oraz w Kijowie (grudzień 1917) opowiedziały się za utworzeniem Ukraińskiej Republiki Rad i już 14(27) grudnia 1917 r. w zajętym przez bolszewickie wojska Charkowie nastąpiło utworzenie Sekretariatu Ludowego Ukraińskiej Republiki Robotniczo-Chłopskiej - pierwszego rządu radzieckiej Ukrainy ${ }^{31}$. Premiera nie powołano; jego obowiązki pełniła Eugenia Bosz (Majsz), sekretarz spraw wewnętrznych ${ }^{32}$. Zauważyć warto ciekawostkę, że w nazwach tek rządowych skopiowano wzory Ukraińskiej Centralnej Rady, a nie piotrogrodzkie Rady Komisarzy Ludowych. Natomiast nowe władze unieważniły wszelkie akty wydane przez UCR i podlegle jej organy.

26 W. Serczyk, op. cit., s. 265.

27 История советской конституиии. Сборник документов. 1917-1957, Издательство Академии Наук СССР, Москва 1957, s. 32-33; История советской конституции (в документах) 1917-1956, Государственное издательство юридической литературы, Москва 1957, s. 74.

О признании Советом Народных Комиссаров Народной Украинской Республики и о предъявленном Центральной Раде ультиматуме ввиду ее контрреволюиионной деятельности, [w:] Нстория советской конституиии. Сборник документов. 1917-1957..., s. 32-33; История советской конституции (в документах) 1917-1956..., s. 74.

29 История советской конституиии. Сборник документов. 1917-1957..., s. 33.

30 Об Украинскои Центральоной Раде. [Резолюиия краевого съезда большевиков Украиныл], [w:] История советской конституиии (в документах) 1917-1956.., s. 77-78.

31 История советской конституиии. Сборник документов. 1917-1957..., s. 33-34.

32 Zob. Е. Бош, Год борьбъи, Киев 1990, s. 144; Аеятели СССР и революиионного движения в России. Энциклопедический словарь Гранат, Москва 1989, s. 367-668. 
Najlepsze jednostki rosyjskich czerwonogwardzistów pod dowództwem zasłużonego bolszewika Włodzimierza Antonowa-Owsiejenki ${ }^{33}$ skierowane zostały przez władze moskiewskie przeciw wojskom Centralnej Rady, ale też w kierunku Zagłębia Donieckiego, naprzeciw wojskom kozackim Kaledina. Z sukcesami czerwonych: obok wcześniej opanowanego Charkowa, zdobyto miasta Zagłębia Donieckiego, Odessę, Mikołajów, Chersoń, Połtawę i inne. W drugiej połowie stycznia $1918 \mathrm{r}$. wybuchło powstanie w Kijowie i mimo ściągnięcia przez Semena Petlurę jednostek frontowych, po długich i zaciekłych walkach, przy pomocy czerwonej gwardii rosyjskiej, bolszewicy odnieśli (8 lutego 1918) zwycięstwo.

Cały czas trwały rokowania w Brześciu. Do Brześcia przybyły dwie delegacje ukraińskie: sowiecka włączona w skład rosyjskiej i reprezentowana przez działaczy ukraińskiego rządu radzieckiego Jurija Medwiediewa i Bazylego (Wasyla) Szachraja oraz UCR z Wsewołodem Hołubowyczem na czele; wobec kategorycznego stanowiska państw centralnych tylko ta druga została uznana i dopuszczona do obrad. Radziecki protest nie został przyjęty do wiadomości ${ }^{34}$. Dla zawarcia traktatu pokojowego z państwami centralnymi konieczne było, by Ukraina stała się podmiotem prawa międzynarodowego odrębnym od Rosji. Centralna Rada 9 (22) stycznia 1918 r. proklamowała więc niezależnym i suwerennym państwem Ukraińską Republikę Ludową ${ }^{35}$, która

33 Władimir Aleksandrowicz Antonow-Owsiejenko, właśc. Owsiejenko (1883-1938), pochodził z rodziny carskiego oficera; od 1902 członek SDPRR związany z mienszewikami, ale jednak ukończył szkołę junkierskiej piechoty w stopniu podporucznika; 1904/1905 służył w Warszawie; skierowany na front z Japonią zdezerterował, by kontynuować działalność rewolucyjną; 1907 ujęty i skazany na karę śmierci zamienioną na 20 lat katorgi, uciekł zaraz po wyroku i działał nadal; 1909 wyemigrował do Francji, gdzie przyjął nazwisko Antonow; 1915 zerwał z mienszewikami i opowiedział się za Leninem; 1917 wrócił do Rosji; prowadził agitację probolszewiką i rewolucyjną w Finlandii i na Łotwie; wszedł w skład Wojskowego Komitetu Rewolucyjnego w Piotrogrodzie i współkierował październikowym zamachem stanu i osobiście poprowadził szturm na Pałac Zimowy, obalając Rząd Tymczasowy; to on wszedł wówczas do sali obrad rządu i powiedział: „W imieniu Komitetu Wojskowo-Rewolucyjnego aresztuję was". W czasie wojny domowej dowodził na froncie ukraińskim; był szefem Zarządu Politycznego Armii Czerwonej; dowódca Piotrogrodzkiego Okręgu Wojskowego; jako bliski współpracownik i zwolennik Trockiego odsunięty przez Stalina od stanowisk kierowniczych i skierowany do pracy w placówkach dyplomatycznych, m.in. w Polsce 1930-1934; pr.rator RSFRR (1934-1936); aresztowany (1937) siedział na Butyrkach; był chory, miał opuchnięte nogi; opowiadał o Leninie, rewolucji, wojnie w Hiszpanii; na przesłuchaniach był nieugięty; niczego nie podpisywał; skazany został na 10 lat, ale to nie przeszkadzało, by niezwłocznie (?) został rozstrzelany; wezwany na egzekucję, rozdał płaszcz, buty, marynarkę współwięźniom i prosił, by kiedyś zaświadczyli, że pozostał bolszewikiem do końca swych dni; zrehabilitowany na XX zjeździe KPZR w 1956. R. Conquest, Wielki terror, tłum. W. Jeżewski, Warszawa 1997, s. 468-469; T. Stryjek, w: Stownik biograficzny Europy Środkowo-Wschodniej, red. W. Roszkowski i J. Kofman, Warszawa 2004, s. 36-37; Leksykon historii powszechnej 1900-1945, red. S. Sierpowski i S. Żerka, Poznań 1996, s. 12-13; Leksykon historii świata: Rosja..., s. 27-28. W. Serczyk, op. cit., s. 266.

Історія держави і права України, Академічний курс, ред. В. Й. Тацій, А. Й. Порожин, Київ 2000, t. 2, s. 50; zob. też W. Serczyk, op. cit., s. 260; też E. Toczek, Wstęp do: Konstytucja Ukrainy uchwalona na piątej sesji Rady Najwyższej Ukrainy 28 czerwca 1996 r., wstęp i tłumaczenie E. Toczek, Warszawa 1999, s. 7. 
została uznana przez państwa centralne, a 9 lutego 1918 r. zawarła z nimi traktat pokojowy. Pretensje UCR do Galicji Wschodniej, Bukowiny i Zakarpacia zostały odrzucone jako wewnętrzne sprawy monarchii austro-węgierskiej. W tajnym protokole uzupełniającym państwa centralne godziły się na włączenie Chełmszczyzny i Podlasia do Ukrainy, zaś Austro-Węgry wyrażały zgodę na połączenie w jeden kraj koronny Galicji Wschodniej i Bukowiny oraz na utworzenie autonomicznej prowincji ukraińskiej. Oczywiście w ramach Austrii, bo przecież umawiające się strony liczyły na zwycięstwo państw centralnych w wojnie światowej. Zarówno sprawa oderwania Chełmszczyzny przypominająca bolesny rok 1912, jak i - ujawniony w maju 1918 r. - tajny traktat dotyczący ukraińskiej autonomii w Galicji Wschodniej, wywołały takie wrzenie i manifestacje ludności polskiej, że Austro-Węgry wycofały się z ustaleń tajnego protokołu unieważniając go ${ }^{36}$. Były to już ostatnie godziny urzędowania UCR w piwnicach budynków rządowych w Kijowie, który zdobywali ukraińscy i rosyjscy bolszewicy wspomagani czerwonogwardzistami Antonowa-Owsiejenki. Ostateczne zdobycie stolicy nastąpiło $\mathrm{w}$ dniu podpisania w Brześciu traktatu URL z państwami centralnymi. UCR ewakuowała się do Żytomierza, a później do Sarn na Wołyniu. Władze Ukrainy sowieckiej przeniosły się z Charkowa do Kijowa. Ukraina znalazła się w rękach bolszewików, którzy mieli duże wpływy wśród ludności ukraińskiej, także mas wiejskich. Przeciąganie rokowań brzeskich przez bolszewików m.in. miało na celu opanowanie Ukrainy przez czerwonych przed podpisaniem traktatu. Dostrzegając te manewry nie tylko na Ukrainie, w trakcie rokowań brzeskich Niemcy w ultimatum żądały niezwłocznego zawarcia pokoju z Ukraińską Republiką Ludową, wycofania jednostek Armii Czerwonej i innych sił zbrojnych z terenów Ukrainy, Finlandii, Inflant, Estonii.

Zerwanie (luty 1918) przez Trockiego rozmów skutkowało uruchomieniem ${ }^{37}$ przez państwa centralne potężnej ofensywy i zaostrzeniem warunków niemieckiego ultimatum. Podpisany w końcu przez stronę radziecką traktat brzeski (3 marca 1918) zawierał postanowienie o opuszczeniu przez wojska czerwonej Rosji terenów Ukrainy oraz o uznaniu traktatu pokojowego między Ukraińską Centralną Radą a państwami centralnymi. Udzielając pomocy Centralnej Radzie Niemcy i Austro-Węgry wprowadzili na Ukrainę swoje armię. Rozpętała się krwawa wojna domowa z siłami ukraińskich bolszewików oraz przybyłych z Rosji czerwonogwardzistów pod dowództwem Antonowa-Owsiejenki, który został mianowany głównodowodzącym sił zbrojnych radzieckiej

36 W. Serczyk, op. cit., s. 266, 284; por. też J. Hrycak, Historia Ukrainy 1772-1999. Narodziny nowoczesnego narodu, tłum. K. Kotyńska, Lublin 2000.

37 Strona niemiecka zawiadomiła telegraficznie Lenina, że od 18 lutego 1918 r. od godziny 12 znajduje się w stanie wojny z Rosją. Zob. o tym L. Trocki, Moje życie. Próba autobiografii, autoryzowany przekład z rosyjskiego J. Barski i S. Łukomski, Warszawa 1930 [reprint Warszawa 1990], s. 430. 
Ukrainy. Przewaga sił niemieckich zmusiła czerwonych do opuszczenia Kijowa, do którego 2 marca 1918 r. powróciła UCR; rząd komunistyczny przeniósł się najpierw do Połtawy, później do Taganrogu.

W ciągu marca - kwietnia 1918 r. przy wsparciu wojsk niemieckich i austriackich tereny Ukrainy zostali uwolnione od wojsk rosyjskich bolszewików. Na podstawie zawartego 3 marca 1918 r. w Brześciu Litewskim pokoju między RSFRR i państwami centralnymi rząd rosyjski zobowiązywał się zawrzeć pokój z URL i w trakcie kolejnych rokowań wytyczyć ukraińsko-rosyjską granicę państwową ${ }^{38}$. URL i RSFRR nawiązały stosunki konsularne. Znaczyło to, że strona rosyjska uznawała suwerenność państwa ukraińskiego. Wszak odnowienie władzy rządu URL nie znaczyło, że odzyskał on pełną suwerenność. Faktycznie Ukraina znalazła się pod kontrolą nowych sojuszników, którzy wprowadzili na jej terytorium prawie 450-tysięczny kontyngent wojskowy ${ }^{39}$. $\mathrm{Na}$ arenie międzynarodowej URL stała się $\mathrm{w}$ efekcie postrzegana jako wróg Ententy, co musiało mieć skutki po porażce państw centralnych w wojnie: URL znalazła się w izolacji dyplomatycznej. Symon Petlura w 1922 r. w liście do generała armii URL Mykoły Udowyczenki pisał: „My do chwili obecnej pokutujemy za ten błąd, bo alianci do dziś nie zapomnieli nam «zdrady» naszej"

Względna stabilizacja sytuacji na Ukrainie nie ułatwiła działalności rzą$\mathrm{du}$ URL. Borykał się on $\mathrm{z}$ opanowaniem chaosu rewolucyjnego spowodowanego bolszewicką agitacją, z potrzebą niezwłocznego zaprowadzenia skutecznej administracji. Centralna Rada i rząd URL - Rada Ministrów Ludowych (tak przemianowano Generalny Sekretariat w styczniu 1918 r.) nadal trzymały się $\mathrm{w}$ polityce wewnętrznej lewicowych poglądów. Przede wszystkim chodziło o zniesienie prywatnej własności ziemi i uchwaleniu ustawy o socjalizacji ziemi. Rząd ukraiński w większości tworzyli ludzi młodzi o niewielkim doświadczeniu politycznym słabo orientujący się w funkcjonowaniu machiny państwowej. Nie potrafili nawiązać kontaktu z wojskowymi władzami niemieckimi i austriackimi. Niemcy i Austro-Węgrzy obawiali się zaś, że strona ukraińska nie wywiąże się ze zobowiązań danych w Brześciu odnośnie dostaw żywności. Korzystając z nieudolności administracji URL Niemcy i Austriacy sami wzięli się za organizację zakupów żywności, dopuszczając się przy tym nadużyć, co wywoływało oburzenie chłopów traktujących ich poczynania jako rekwizycje wojenne. Jeszcze bardziej podsycały nastroje powrót pod osłoną wojsk niemieckich i austro-węgierskich byłych właścicieli ziem-

38 Аипломатический словарь. Главная редакция А. А. Громыко, А. Г. Ковалев, П. П. Севостьянов и др., t. 1, Москва 1985, s. 155.

39 Історія Української РСР: У 8 m., t. 5, Київ 1977, s. 281.

40 С. Петлюра, Аист до генерала-хорунжого Миколи Удовиченка, [w:] Симон Петлюра. Статті, Київ 1993, s. 223. 
skich i represje wobec chłopów za udział w podziale gruntów, co było zresztą przeprowadzone zgodnie $\mathrm{z}$ ustawodawstwem agrarnym Centralnej Rady i zarządzeniami rządu URL. W rezultacie chłopi zwlekali z zasiewem zboża nie będąc pewnymi, czy nie zostanie im odebrana przydzielona ziemia. To jeszcze bardziej wywoływało nerwowość niemieckiego i austro-węgierskiego dowództwa.

Już w kwietniu 1918 r. przeciwko Centralnej Radzie powstała potężna opozycja. Przeciwko istniejącemu reżimowi, odczuwając poparcie niemieckie i austro-węgierskie, otwarcie wypowiadali się właściciele ziemscy, a nawet zamożni chłopi niezadowoleni z socjalistycznych eksperymentów przywódców. Niezamożne chłopstwo także czuło się zawiedzone brakiem postępu $\mathrm{w}$ realizacji reformy rolnej, a szczególnie obawiało się powrotu byłych właścicieli ziemskich. Ludność nieukraińska, która była wrogo nastawiona do państwowości ukraińskiej, z kolei obarczała Centralną Radę, że ta dołączyła do wrogów Rosji odrywając Ukrainę od Rosji. Obecność na Ukrainie wojsk niemieckich i austro-węgierskich sprzyjała wzmacnianiu i konsolidowaniu się opozycji. Ta zaś garnęła się do organizacji Ukraińska Gromada, założonej przez siły konserwatywne, na czele których stał były dowódca 1 Ukraińskiego Korpusu generał Paweł Skoropadski. Powstanie opozycji wzbudziło zainteresowanie dowództwa niemieckiego, które coraz bardziej przekonywało się o niemożności kontynuowania wspólpracy z Centralną Radą i planowało odsunięcie jej od władzy i zamianę na lojalniejszy rząd. Z początkiem kwietnia 1918 r. rozpoczęły się intensywne konsultacje pomiędzy dowództwem niemieckim a generałem Skoropadskim na temat planowanego zamachu stanu. Zapewniwszy sobie neutralność Niemców, Skoropadski wydał rozkaz rozpoczęcia werbunku oficerów w Kijowie ${ }^{41}$, co w ówczesnych warunkach było łatwe. Wieczorem 24 kwietnia Skoropadski zwołał naradę, na której omówiono szczegóły planowanego zamachu stanu i warunki na jakich strona niemiecka godziła się wspólpracować z nowym reżimem. 26 kwietnia dowódca wojsk niemieckich na Ukrainie feldmarszałek Hermann von Eichhorn wydał rozkaz o powołaniu niemieckich sądów polowych. Centralna Rada wyraziła w związku z tym protest, traktując to jako ingerencję $\mathrm{w}$ wewnętrzne sprawy URL. Faktycznie był to początek zamachu stanu. W nocy z 26 na 27 kwietnia oddziały niemieckie rozbroiły jednostki wojskowe Centralnej Rady, z wyjątkiem pułku Strzelców Siczowych, a następnego dnia Niemcy aresztowali niektórych ministrów rządu. Najwyższe władze URL nawet nie podjęły próby przeciwstawienia się zamachowi. W ciągu dnia 29 kwietnia zwolennicy Skoropadskiego prawie bez oporu zajęli gmachy urzędów państwowych, z wyjątkiem gmachu Centralnej Rady. Tegoż dnia, który okazał się ostatnim w jej historii, UCR usiłowała

41 П. Скоропадський, Спогади. Кінець 1917 - грудень 1918, Київ, Філадельфія 1995, s. 141. 
uchwalić konstytucję URL. Mychajło Hruszewski nadal pozostawał na stanowisku jej przewodniczącego. Jednak należy podkreślić, że w tekście konstytucji określenia "prezydent” nie spotykamy, użyto natomiast tu jako odpowiednika słowa "prezes” (przewodniczący - голова). Sam Hruszewski na wizytówce miał: President du Parlament D'Ukraine. Trzeba przyjąć, że de facto przez kilkanaście godzin pełnił on funkcję prezydenta republiki ${ }^{42}$. Według konstytucji URL była republiką parlamentarną. Najwyższym organem ustawodawczym wybranym w powszechnych, równych, bezpośrednich i proporcjonalnych wyborach miał być parlament - Zgromadzenie Ogólnonarodowe (Всенароднi 3бори) o trzyletniej kadencji, które miało zastąpić Centralną Radę. Czynne prawo wyborcze uzyskali wszyscy, którzy ukończyli 20 lat, bez różnicy płci, wiary, pochodzenia społecznego. Prezes (przewodniczący) Zgromadzenia wraz z Radą Seniorów Zgromadzenia powoływał rząd, ale ten akt musiał uzyskać zatwierdzenie całego Zgromadzenia. Ministrowie ponosili przed Zgromadzeniem odpowiedzialność parlamentarną indywidualną i solidarną. Zgromadzenie wybierało Sąd Generalny. Konstytucja przewidywała także nowy administracyjny podział kraju, który w radykalny sposób zrywał z rozwiązaniami czasów carskich ${ }^{43}$. Ustawa zasadnicza odzwierciedlała ideologię państwowotwórczą ówczesnych przywódców ukraińskich i miała ustawodawczo potwierdzić tę formę państwa, która ukształtowała się w ciągu 1917 i w pierwszej połowie $1918 \mathrm{r}$.

29 kwietnia niemiecka władza wojskowa rozwiązała Centralną Radę ${ }^{44}$. W tym samym czasie $\mathrm{w}$ Kijowie zebrał się Zjazd Włościański z udziałem 6432 delegatów z ośmiu (spośród dziewięciu) guberni, reprezentujących ziemiaństwo i zamożnych chłopów, a także warstwy przemysłowe, finansowe. Ogółem w zjeździe brało udział około 8 tys. uczestników ${ }^{45}$. Po ostrej krytyce Centralnej Rady i rządu URL niezdolności zaprowadzenia porządku w państwie i skutecznie działającej administracji uczestnicy Zjazdu obwołali hetmanem Ukrainy generała P. Skoropadskiego ${ }^{46}$. W swoim krótkim wystąpieniu, przypominającym expose, Skoropadski mówił głównie o tym, że „wszędzie szerzy się anarchia i że tylko twarda władza zdolna jest zaprowadzić porządek" ${ }^{\prime 4}$.

42 Я. Малик, Михайло Грушевський: незбитий шлях. Нариси життя та діяльності, Аьвів 2016, s. 198-199; tak uważa też A. Olechno, Instytucja Prezydenta w systemie konstytucyjnych organów Ukrainy (1996-2005), Toruń 2009, s. 13; idem, Instytucja prezydenta na tle początków państwowości ukraińskiej, „Miscellanea Historico-Iuridica” 2009, t. VIII, s. 112.

43 Конституиійні акти України 1917-1920. Невідомі конституиії Украйни, Київ 1992, s. 73-79.

44 Є. Коновалець, Причинки до історії Украӥнської револючї̈, Прага 1928, s. 7.

45 В. Верига, Визвольні змагання в Україні 1914-1923, t. 1, Аьвів 1998, s. 288.

46 В. Верига, Визвольні змагання..., t. 1, s. 289; М. Омелянович-Павленко, Спогади украйнського командарма, Київ 2002, s. 62-63.

47 Т. Андрусяк, Правові основи украӥнської гетьманської держави 1918 року, [w]: Останній гетьман. Ювілейний збірник пам'яті Павла СкоропаАського 1873-1945, Київ 1993, s. 87. 


\section{Zwrot ku przeszłości}

Objęcie władzy przez Skoropadskiego zmieniło formę dotychczasowego ustroju państwa. Nawet sama jego oficjalna nazwa - Ukraińskie Państwo (Украӥнська Аержава Ukrajinśka Derżawa) - miała podkreślić różnice w stosunku do URL. Ukraina przestała być republiką, a przybrała formę przypominającą połączenie dyktatury wojskowej i monarchii. Podstawy prawne nowego reżimu określały: Akt do narodu ukraińskiego („Грамота до украї нського народу") i Ustawa o tymczasowym ustroju państwowym Ukrainy, wydane przez P. Skoropadskiego 29 kwietnia 1918 r. ${ }^{48}$ Ta ostatnia została niemal skopiowana z ustawy carskiej z $1906 \mathrm{r}^{49}$ Dokumenty te przewidywały zwołanie Zgromadzenia Ustawodawczego, lecz nie określały jego kompetencji. Nigdy się ono nie zebrało. Quasi-monarchiczny charakter reżimu przejawiał się w tym, że Hetmanowi przysługiwały najwyższe uprawnienia władcze: zatwierdzanie i sankcjonowanie wszystkich ustaw, mianowanie premiera rządu, a na jego wniosek członków Rady Ministrów, odwołanie rządu, mianowanie na wyższe urzędy administracji państwowej i odwoływanie z nich. Rząd podlegał bezpośrednio Hetmanowi. Do kompetencji głowy państwa należało dowództwo nad siłami zbrojnymi, wprowadzenie $\mathrm{w}$ państwie lub na części jego terytorium stanu nadzwyczajnego, prowadzenie polityki zagranicznej. Hetman posiadał prawo ułaskawienia ( $w$ tym łagodzenia kary), nadawania poszczególnym osobom przywilejów, jeżeli te nie naruszają praw innych obywateli. Tryb legislacyjny był następujący: przygotowane $\mathrm{w}$ ministerstwach projekty rozpatrywała Rada Ministrów, a następnie zatwierdzał Hetman. Zgromadzenie Ustawodawcze $\mathrm{w}$ tej procedurze nie uczestniczyło, ponieważ nie było jeszcze wybrane.

Na czele struktury sądownictwa stał Sąd Generalny, ustanowiony jeszcze w czasach Centralnej Rady, ale obecnie sędziowie byli mianowani przez Hetmana. Wkrótce (8 lipca 1918 r.) został przekształcony w Państwowy Senat. Senat na czele z prezydentem dzielił się na trzy generalne sądy (na podobieństwo departamentów): administracyjny, cywilny i karny. Liczył 45 osób: prezydent, senatorowie zebrania ogólnego, senatorowie sądów generalnych ${ }^{50}$.

Reżim hetmanatu jako forma ustroju nie został zdefiniowany $\mathrm{w}$ literaturze historycznej. Komplikuje sprawę obecność na Ukrainie wojsk niemieckich oraz austro-węgierskich i wpływ Berlina i Wiednia na sytuację w kraju i na kształt samego państwa. Ciekawostką jest ostra reakcja Wiednia na tytuł Sko-

\footnotetext{
48 Конституиійні акти Украӥни 1917-1920. Невідомі конституиї Украӥни, s. 82-86; О. Реєнт, Павло Скоропадський, Київ 2003, s. 87-89; В. С. Кульчицький, М. І. Настюк, Б. Й Тищик, 3 історіі української державності, Аьвів 1992, s. 69-70.

49 Свод основньгх государственных законов, Санкт-Петербург 1906, t. 1, сz. 1; Из киевских воспоминаний А. А. Гольденвейзера, [w:] Архив русской революиии, t. 6, Москва 1991, s. 217-218.

50 О. I. Аупандін, Аержавний сенат Украйнської держави 1918, [w]: Енииклопедія історії Украӥни: у 10 т., Редкол.: В. А. Смолій (голова) та ін., Київ 2004, t. 2, s. 353.
} 
ropadskiego: „Hetman całej Ukrainy”, ponieważ dopatrzono się w tym jego roszczenia do Galicji i Bukowiny. Incydent załagodził Berlin. W akcie uznania Państwa Ukraińskiego użyto formułę „Jego Ekscelencja Paweł Skoropadski, Hetman Ukrainy”. Sam hetman podpisywał akty państwowe jako „Hetman całej Ukrainy i wojsk kozackich".

Dyktatorskie upoważnienia hetmana znajdowały grunt w przekonaniu, że jedynym środkiem, przy pomocy którego można wydobyć państwo z chaosu jest silna władza głowy państwa i sprawnie działająca administracja. Nie wiadomo, czy Skoropadski naprawdę pragnął założyć własną dynastię na Ukrainie. W oświadczeniu Rady Ministrów wydanym 10 maja 1918 r. stwierdzało się, że „Hetman nie myśli być samodzierżawcą. Nazwa hetman tkwi w historycznej i narodowo-ukraińskiej tradycji idei niepodległej i wolnej Ukrainy. Stojąc na czele rządu ukraińskiego hetman w taki sposób odnawia i wzmacnia $\mathrm{w}$ świadomości ludowej myśl o naturalnych ludowych i kozackich wolnościach" ${ }^{51}$. Na początku XX w. takich tradycji już realnie nie było, bo zniszczyła to Rosja. Były to sztuczne próby łączenia pewnych archaizmów z instytucjami państwowymi: np. przewodniczący rady ministrów mianował się atamanem, wyższe stopnie oficerskie przemianowano według wzorca czasów kozackich: generalni buńczukowi, znaczkowi i tym podobne. Wkrótce $\mathrm{z}$ tego zrezygnowano. Paweł Skoropadski miał oficjalny tytuł ,jaśnie wielmożny pan hetman całej Ukrainy", akta z jego podpisem wydawane były w formie aktów urzędowych („gramot"), manifestów, listów. Przyszłą polityczną reformę Skoropadski upatrywał w taki sposób, że nie będzie to dyktaturą wyższej klasy, ani dyktaturą proletariatu, a równorzędnym uczestnictwem wszystkich klas społeczeństwa w politycznym życiu kraju ${ }^{52}$. Jednak był przekonany, że „Ukraina może istnieć tylko w kształcie hetmanatu. Oczywiście rola hetmana musi być mocno ograniczona $\mathrm{w}$ porównaniu $\mathrm{z}$ tymi uprawnieniami, które sobie tymczasowo przywłaszczyłem dla przeprowadzenia $\mathrm{w}$ życie tych planów, jakie $\mathrm{w}$ żaden inny sposób nie można zrealizować" 53 .

Skoropadski i jego rząd sporo uwagi poświęcali - w sposób typowy dla dyktatorów - rozbudowie organów ochrony państwa, a także wywiadu i kontrwywiadu ${ }^{54}$. Wśród nich najważniejszą rolę pełniła Straż Państwowa. Była instytucja mundurową i wykonywała zadania policji i żandarmerii, podobnie jak w czasach carskich. Wśród swoich obowiązków miała ochronę ustroju państwowego, porządku publicznego, ścigania czynów o charakterze politycz-

51 О. Реєнт, Павло Скоропадський, s. 91.

52

О. А. Гавриленко, І. А. Аогвиненко, Гетьманський переворот 29 квітня 1918 р.: причини та наслідки, [w]: Актуальні проблеми юридичної науки в дослідженнях виених: науково-практичний збірник, nr 3, Київ 2000, s. 2-10.

П. Скоропадський, Спогади. Кінець 1917 - грудень 1918, s. 182.

54

В. С. Сідак, Національні спецслужби в період Української революиї 1917-1921 рр. (невідомі сторінки історіi), Київ 1998, s. $84-120$. 
nym, tłumienia buntów i innych wykroczeń przeciwko władzy hetmańskiej, ale także ścigania przestępstw kryminalnych. Rabunki, morderstwa, gwałty, zamachy terrorystyczne, samowolne areszty i różnego rodzaju wykroczenia zdemobilizowanych żołnierzy i zwolnionych poprzednio więźniów kryminalnych były zjawiskiem powszednim. Podsycała chaos opozycja: rosyjscy bolszewicy, monarchiści i ukraińskie środowiska lewicowe. Straż Państwowa podporządkowana była Ministerstwu Spraw Wewnętrznych, a w terenie starostom gubernialnym i powiatowym. Funkcjonariusze Straży byli dobrze opłacani ${ }^{55}$. Nawiązując do organów bezpieczeństwa czasów hetmanatu trzeba podkreślić, że $\mathrm{w}$ ramach własnego sztabu hetmana powstały specjalne struktury zajmujące się wyłącznie ochroną głowy państwa i reżimu politycznego. Przez nie hetman bezpośrednio zdobywał interesującą go informację o sytuacji w kraju. Miało to uniezależnić go od Ministerstwa Spraw Wewnętrznych i zweryfikować informacje ${ }^{56}$.

Za czasów rządów Skoropadskiego podjęto starania w kierunku rozwoju państwowej służby cywilnej. Po zamachu stanu hetman pozostawił na poprzednich stanowiskach (oprócz ministrów i ich zastępców) wykwalifikowanych urzędników, a także pragnął przyciągnąć do pracy w administracji państwowej fachowców. W tym celu została uchwalona ustawa O porządku mianowania do stużby państwowej, która reglamentowała kategorię urzędników mianowanych na odpowiednie urzędy przez hetmana lub ministra. Faktycznie ustawa o służbie cywilnej kopiowała odpowiednią ustawę cesarstwa rosyjskiego. Wszyscy urzędnicy składali przysięgę na wierność państwu i władzy ${ }^{57}$.

Działalność Skoropadskiego w kierunku usprawnienia administracji państwowej rychło skutkowała pozytywnymi wynikami. Ciekawe obserwacji o działalności hetmańskiego rządu zanotował we wspomnieniach kijowski adwokat Wiktor Andrijewski. „Pierwsze kroki nowego gabinetu ministrów w każdym razie odbierano pozytywnie. Odczuwano twardą rękę ludzi, którzy rozumieją się na sprawach, władają i umieją wykazywać inicjatywę, a nie poszukują - jak ich poprzednicy - „poparcia ludu”, nie czerpią państwowej mądrości z programów partyjnych, a doświadczenia ze zjazdów, obrad i temu podobnych niepewnych źródeł. Machina państwowa gładko zaczęła pracować w krótkim czasie" 58 .

Hetman Skoropadski podjął starania w kierunku usprawnienia działalności administracji terenowej i samorządu terytorialnego. Z poprzedniego okresu po-

55 О. Мироненко, Аержавна варта, [w]: Мала енииклопедія етнодержавознавства, Київ 1996, s. 280-282.

56 В. Сідак, Національні спецслужби в період Украӥнської револющї 1917-1921 рр., s. 113; П. Скоропадський, Спогади. Кінець 1917 - грудень 1918, s. 207.

О. Реєнт, Павло Скоропадсъкий, s. 94. 
zostawiono terytorialny podział Ukrainy na gubernie i powiaty. Państwo dzieliło się na 9 guberni, a te na powiaty na czele ze starostami. Starostowie gubernialni mieli kompetencje dawnych carskich gubernatorów. Ponieważ ukraińska opozycja odrzuciła współpracę z hetmanem, ten był zmuszony - wobec braku wykwalifikowanych urzędników - obsadzać stanowiska w administracji terenowej osobami poniekąd wrogo nastawionymi do państwowości ukraińskiej. W maju 1918 r. wszczęto kroki w kierunku udoskonalenia samorządu terytorialnego. Okazało się, że organa samorządowe często sabotowały zarządzenia organów administracji państwowej lub odmawiały z nią współpracy. W celu eliminowania podobnych zjawisk w administracji lokalnej 29 czerwca $1918 \mathrm{r}$. rząd przyjął ustawę, według której starosta gubernialny w określonych przypadkach, za zezwoleniem ministra spraw wewnętrznych, mógł rozwiązywać organy samorządowe. Na początku września 1918 r. uchwalono ustawę o wyborach do lokalnych organów samorządowych - ziemstw. Jej realizacja została przerwana upadkiem hetmanatu ${ }^{59}$.

Ważne miejsce $\mathrm{w}$ działalności hetmana zajmowały sprawy wojskowe. Niemcy i Austro-Węgry niechętnie patrzyli na przedsięwzięcia Skoropadskiego w tym zakresie, ponieważ pragnęli zachować nad Ukrainą jak najdalej idącą kontrolę. Szef sztabu wojsk niemieckich na Ukrainie generał Wilhelm Groener próbował przekonać hetmana o zbędności tworzenia armii ukraińskiej, zapewnią zarówno ład wewnętrzny, jak też bezpieczeństwo od wtargnięcia bolszewików z północy ${ }^{60}$. Wbrew temu Skoropadski powoli rozpoczął formowanie ukraińskich sił zbrojnych. Zasadą jego polityki wojskowej, w odróżnieniu od czasów rządów Centralnej Rady, było usunięcie z wojska polityki.

Czas rządów Pawła Skoropadskiego był krótkim okresem stabilności na Ukrainie. W Kijowie akredytowano 11 misji dyplomatycznych państw obcych, a Ukraina nawiązała kontakty z 10 państwami ${ }^{61}$. Oczywiście, przede wszystkim stabilność była zapewnona przez obecność wojsk niemieckich i austriackich. W sposób zasadniczy ograniczało to suwerenność rządu Skoropadskiego w polityce zagranicznej, ponieważ pozbawiało go możliwości manewru i wyboru orientacji $\mathrm{w}$ polityce międzynarodowej. $\mathrm{W}$ oczach opozycji, do której należała większość ówczesnych ukraińskich środowisk politycznych, był sługą niemieckich i austriackich "sojuszników”. Szkodę autorytetowi władzy hetmańskiej przynosiły rekwizycje żywności przeprowadzane przez wojska austriackie i niemieckie. Szczególne niezadowolenie, wręcz nienawiść do władzy hetmańskiej wśród masy chłopstwa ukraińskiego wywołały ekspedycje karne organizowane na własną rękę przez byłych właścicieli ziemskich, którzy w celu rekompensaty za zniszone w czasie rewolucji majątki nakładli na

59 О. Реєнт, Павло Скоропадський, s. 112-116.

60 П. Скоропадський, Спогади. Кінець 1917 - грудень 1918, s. 179.

61 Нариси з історії дипломатії України. (Під ред. В. А. Смолія), Київ 2001, s. 327. 
wsie ogromne kontrybucje. W większości oddziały karne tworzyły się z bezrobotnych oficerów byłej armii carskiej, dziesiątki tysięcy których fala rewolucyjna wyrzuciła z Rosji bolszewickiej. Trudno stwierdzić czy Skoropadski był $\mathrm{w}$ stanie temu zapobiec, ale prawdopodobnie wiedział o represjach wobec zbuntowanego chłopstwa ${ }^{62}$. Szowinistycznie nastawieni rosyjscy oficerowie nie akceptowali państwowości ukraińskiej uważając ją za zjawisko tymczasowe, wręcz szkodliwe dla Rosji i często swoimi postępkami dyskredytowali władze ukraińskie. Bunty chłopskie, które wybuchały w różnych miejscowoąciach były rozpędzane przez Strażą Państwową, oddziały niemieckie i austriackie. Stabilność w Państwie Ukraińskim była pozorna ${ }^{63}$.

Chociaż Ukraina została oczyszczona z wojsk bolszewickich, a jej granice zostały obsadzone wojskiem niemieckim i austriackim, formalnie nadal znajdowała się w stanie wojny z RSFRR. Zgodnie z brzeskim układem pokojowym (3 marca 1918) RSFRR zobowiązana była podpisać układ pokojowy z Ukrainą. Po dość długiej zwłoce rząd RSFRR wyraził zgodę na wysłanie delegacji pokojowej do Kijowa. Po dyskusjach 12 czerwca 1918 r. został podpisany preliminarny układ pokojowy między Ukrainą a RSFRR ${ }^{64}$. Delegacja rosyjska zwlekała z podpisaniem ostatecznej umowy pokojowej spodziewając się na porażki Niemiec i Austro-Węgier w wojnie i chciała zachować swobodę działań wobec Ukrainy, co się stało po 11 listopada 1918 r. Między granicami RSFRR i Ukrainy ustanowiono 10-40-kilometrową "neutralną strefę" której nie miała prawa przekraczać żadna ukraińska czy rosyjska formacja zbrojna ${ }^{65}$.

W okresie hetmanatu osobne zagadnienie stanowiła rekrutacja kadry urzędniczej. Po przewrocie państwowym lewicowe środowiska ukraińskie odmówili uczestnictwa $\mathrm{w}$ administracji nie chcąc kompromitować się współpracą $\mathrm{z}$ reżimem reakcyjnym. Ponieważ właśnie $\mathrm{w}$ tym środowisku skupiała się zdecydowana większość inteligentnych sił ukraińskich, a narodowe prawicowe konserwatywne środowisko było zbyt słabe, żeby opanować machinę państwową, hetman był zmuszony zwrócić się do dawnej biurokracji, która zajmowała w kwestii ukraińskiej stanowisko neutralne lub otwarcie wrogie. Wywołało to ze strony ukraińskich lewicowych polityków ostrą krytykę hetmanatu jako tylko formalnie ukraińskiego państwa, lecz w gruncie rzeczy rosyjskiego. Już w maju 1918 r. powstał opozycyjny blok, który od września

62 Ю. Тютюнник, Революиійна стихія. Зимовий похід 1919-20 рр., Аьвів 2004, s. 58-59; А. Аорошенко, Мої спомини про недавне минуле (1914-1920), Київ 2007, s. 326.

63 Zob.: В. Верига, Визвольні змагання в Україні 1914-1923, t. 1, s. 313-318; I. Мазепа, Україна в огні й бурі революиії 1917-1921, Київ 2003, s. 60-61; В. Аободаєв, Революиійна стихія. Вільнокозацький рух в Україні 1917-1918 рр., Київ 2010, s. 212-222.

64 Мирні переговори між Украйнською Аержавою та РСФР 1918 р. Протоколи і стенограми пленарних засідань. Збірник документів і матеріалів, Київ, Нью-Йорк, Філадельфія 1999, s. 299-300.

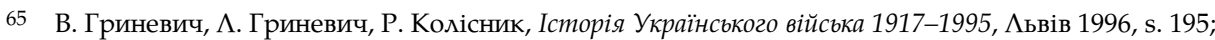
Великий жовтень і громадянська війна на Україні. Енциклопедииний довідник, Київ 1987, s. 367. 
tegoż roku przybrał nazwę Ukraiński Narodowy Sojusz pod przewodnictwem byłego premiera rządu URL Włodzimierza Wynnyczenki. Blok jako swój cel postawił obalenie hetmanatu i restytucję URL. Zdecydowanie wrogą postawę wobec Skoropadskiego zajęli bolszewicy i rosyjscy szowiniści. Chociaż każda z tych sił stawiała inne cele, to solidaryzowali się na płaszczyźnie walki przeciw hetmanatowi. Na kryzys wewnętrzny nałożyła się niesprzyjająca koniunktura międzynarodowa. We wrześniu 1918 r. na frontach zachodnim i bałkańskim sojusznicy Ukrainy - państwa centralne - doznali klęski i wkrótce podpisali z Ententą rozejm. Jak wiadomo, bolszewicy anulowali (13 listopada 1918) separatystyczny traktat brzeski. Zatem żadnych formalnych przeszkód dla inwazji rosyjskich wojsk bolszewickich na Ukrainę już nie było. Utrata niemiecko-austriackiego wsparcia i brak własnej silnej armii zmusiły Skoropadskiego do radykalnej zmiany koncepcji polityki zagranicznej: od sojuszniczych stosunków z krajami bloku centralnego do zbliżenia się z Ententą. Ta ostatnia stanowczo odrzuciła możliwość uznania niezależności Ukrainy i jako warunek poparcia reżimu Skoropadskiego postawiła federację z przyszłą niebolszewicką Rosją ${ }^{66}$. W zaistniałej sytuacji 14 listopada 1918 r. Skoropadski proklamował akt federacyjny, którym kasował niepodległość Ukraińskiego Państwa i deklarował zamiar sfederalizowania go w przyszłości z niebolszewicką Rosją. Antyhetmańskie nastroje, które i bez tego stale nasilały się, przerosły w otwarte powstanie. Na jego czele stał Dyrektoriat w składzie pięciu osób. Wśród nich tylko dwie osoby - Włodzimierz Wynnyczenko jako jego prezes i Symon Petlura jako dowódca (główny ataman) wojsk powstańczych - były znane szerszemu ogółowi. Tego samego dnia (14 listopada 1918) Dyrektoriat ogłosił powstanie przeciw hetmanowi i proklamował odnowienie URL. Zalążkiem armii Dyrektoriatu stał się oddział Strzelców Siczowych pod dowództwem pułkownika Eugeniusza Konowalca, stacjonujący w Białej Cerkwi (816 szeregowców i 46 oficerów), czyli zbyt mało i nie zapowiadało zwycięstwa nad siłami hetmańskimi. W tym czasie Skoropadski dysponował 65 tys. wojskiem, ale jego lojalność wobec hetmana była bardzo krucha; wielu oficerów było zwolennikami Dyrektoriatu. Należy wziąć pod uwagę to, że po proklamowaniu powstania siły Dyrektoriatu szybko zwiększały się sięgając do połowy grudnia - według szacunków generała Mykoły Kapusciańskiego - 300 tys. osób ${ }^{67}$. Jednak na początku jego przywódcy, licząc się z brakiem swoich regularnych sił zbrojnych, szukali poparcia rosyjskich bolszewików. Jak przyznawał W. Wynnyczenko, „oni zgadzali się poprzeć nas nie aktywnie, a wzmacnianiem swojej działalności

66 П. Скоропадський, Спогади. Кінеиь 1917 - грудень 1918, s. 303-305; О. Реєнт, Павло Скоропадський, s. 230-237; В. Верига, Визвольні змагання..., t. 2, s. 375-377; М. Шкільник, Украйна у боротьбі за Аержавність в 1917-1921 роках: Спомини і роздуми, Торонто 1971, s. 302.

67 М. Капустянський, Похід украӥнських армій на Київ - Одесу в 1919 роиі. (Короткий воєнно-історииний огляд), t. 1, Мюнхен 1946, s. 20. 
wywiadowczej na frontach, żeby tym przyciągnąć uwagę niemiecko-hetmańskich wojsk. Zobowiązywali się uznać ten ustrój, który będzie ustanowiony przez nową władzę i absolutnie nie wtrącać się w wewnętrzne sprawy Samodzielnej Ludowej Republiki"68. Tak oto liderzy powstania swoimi działaniami prowokowali Federację Rosyjską do ingerencji w ukraińskie sprawy. W lipcu 1918 r. w Moskwie utworzono Komunistyczną Partię (bolszewików) Ukrainy, na czele z Georgijem Piatakowem, wchodzącą w skład Rosyjskiej Komunistycznej Partii (bolszewików). Partia przez następne dziesięciolecie miała w większości członków narodowości rosyjskiej. Na zjeździe założycielskim podjęto decyzję o likwidacji rządu sowieckiego Ukrainy i powołaniu w to miejsce Centralnego Komitetu Wojskowo-Rewolucyjnego. Bolszewicy próbowali wzniecić swoje powstanie, ale jako zupełnie nieprzygotowani ponieśli całkowitą klęskę i wiele ofiar; m.in. Piatakow został usunięty ze stanowiska. Teraz trafiła się okazja do powrotu.

Przywódcy przygotowywanego przewrotu prowadzili rozmowy z Niemcami w celu zapewnienia sobie ich neutralności. Rewolucja w Niemczech skutkowała powstawaniem rad żołnierskich $\mathrm{w}$ armii niemieckiej i to z nimi pertraktował Dyrektoriat. Osiągnięto (16 listopada 1918) porozumienie co do neutralności Niemców i dwa dni później wojska hetmańskie zostały rozbite przez siły Dyrektoriatu. Wkrótce (grudzień 1918) wojska Dyrektoriatu zdobyły Kijów. 14 grudnia 1918 r. P. Skoropadski zrzekł się władzy, przekazując ją gabinetowi ministrów i przy pomocy niemieckich oficerów niebawem wyjechał z Ukrainy ${ }^{69}$. Z kolei rząd jeszcze tego samego dnia przekazał całą władzę Dyrektoriatowi.

\section{Restytucja URL i walka o suwerenność}

Upadek hetmanatu Skoropadskiego oczywiście był zwycięstwem sił demokratycznych, lecz zarazem spowodował prawie zupełną ruinę machiny państwowej. Po wkroczeniu do Kijowa wojsk republikańskich, 18 grudnia $1918 \mathrm{r}$. przyjechał tu z Winnicy Dyrektoriat i 26 grudnia uchwalił oraz ogłosił deklarację, w której ogólnie określono kształt nowej formy państwa, jego najwyższe organa władzy oraz zasady polityki wewnętrznej i międzynarodowej. Deklarację w pewnym sensie można rozpatrywać jako tymczasową konstytucję. Proklamowała odnowienie URL, formalnie uchyliła ustawodawstwo poprzedniego reżimu wracając do ustawodawstwa Centralnej Rady. Wszak restytucja republikańskiej formy rządów nie znaczyła, że całkiem odtworzono status quo z wio-

68 В. Винниченко, Відродження начї: (Історія украӥнської революиї, марець 1917 р. - грудень 1919 р.). у 3 m. (Репринт. відтворення вид. 1920 р.), t. 3, Київ 1990, s. 158.

69

Н. Полонська-Василенко, Історія Украйни, t. 2, Київ 1992, s. 515. 
sny 1918 r. Najpierw zmienił się kształt najwyższych organów państwowych oraz ich kompetencje. Jeszcze w połowie listopada 1918 r. Dyrektoriat był odpowiedzialny przed Ukraińskim Narodowym Sojuszem, który reprezentował opozycyjne wobec hetmanatu siły polityczne. Ale już w odezwie z 15 listopada tytułuje się najwyższym organem państwowym, a w deklaracji z 26 grudnia „najwyższą władzą Ukraińskiej Republiki Ludowej”. W tejże deklaracji stwierdzono, że „Dyrektoriat jest tymczasową najwyższą władzą w okresie rewolucyjnym. Otrzymawszy na czas walki siłę i prawo zarządu państwem od pierwszego źródła rewolucyjnego prawa - ludu pracującego, Dyrektoriat przekaże swoje pełnomocnictwa temuż samemu ludowi"70. Dyrektoriat oznajmił, że pełnia praw w URL odtąd należy wyłącznie do ludu pracującego: chłopstwa, robotników i inteligencji pracującej. Ten lud miał wybrać Kongres Pracy, który byłby najwyższym organem ustawodawczym i zadecydowałby o kształcie centralnych i lokalnych władz państwowych. W przyszłości Kongres miał przekazać swoje upoważnienia Zgromadzeniu Ustawodawczemu, do którego wybory miały nastąpić po stabilizacji sytuacji $\mathrm{w}$ kraju. W taki sposób zapowiedziano wprowadzenie demokracji ograniczonej pod względem klasowym. Eliminowanie z życia publicznego warstw zamożnych utrudniało wykorzystanie inteligencji, niezbędnej dla obsadzenia administracji państwowej.

Najwyższym organem wykonawczym, według wspomnianej deklaracji, był rząd: pierwotnie Rada Komisarzy jako instytucja tymczasowa, a od 26 listopada Rada Ludowych Ministrów, powołana przez Dyrektoriat i przed nim odpowiedzialna. Od początku działalności składała się z 19 osób oddelegowanych przez partie, które brały udział $\mathrm{w}$ przewrocie ${ }^{71}$. Przed rządem stało bardzo trudne zadanie transformowania systemu politycznego i zarządu państwem. 14 stycznia 1919 r. Dyrektoriat uchwalił zwolnienie ze stanowisk wszystkich urzędników centralnej i lokalnej administracji, mianowanych przez hetmana. Powtórne mianowanie ich na urzędy wymagało specjalnej procedury. Podjęcie ważnych dla państwa spraw często odbywało się na wspólnych posiedzeniach Dyrektoriatu i rządu. Prawo inicjatywy ustawodawczej przysługiwało zarówno Dyrektoriatowi, jak i rządowi, poszczególnym ministrom i przewodniczącym resortów ${ }^{72}$.

Nie należy zapominać o pojawieniu się wówczas jeszcze jednego ośrodka władzy ukraińskiej. Ukraińcy z terenów byłego zaboru austriackiego w październiku 1918 r. utworzyli Ukraińską Radę Narodową i proklamo-

\footnotetext{
70 Аиректорія, Рада Народних Міністрів Украӥнської Народної Республіки. Аистопад 1918 - листопад 1920 рр.: Аок. і матеріали. У 2-х томах, 3-х иастинах, t. 2, Київ 2006, s. 391.

71 В. Верига, Визвольні змагання..., t. 2, s. 10; В.Ф. Солдатенко, Украйнська революиія. Історииний нарис, Київ 1999, s. 570-571.

72 Аиректорія, Рада Народних Міністрів Української Народної Республіки. Аистопад 1918 - листопад 1920 pp., t. 2, s. 395.
} 
wali (13 listopada 1918) niezależne państwo Zachodnioukraińską Republikę Ludową [ZURL]. Natychmiast znalazła się ona w stanie wojny z Polską. Walczyły z nią także siły radzieckie. Zachodnioukraińska Republika Ludowa zdecydowała się na połączenie (22 stycznia 1919) federacyjne z rządzoną przez Dyrektoriat Ukraińską Republiką Ludową, co zresztą nie weszło w życie ${ }^{73}$. Akt zjednoczenia obu republik miał przede wszystkim zamanifestować wspólne pragnienie Ukraińców do jednego i niepodległego państwa. Faktycznie ZURL, zwana od tego czasu Zachodnim Obwodem URL (ZOURL), tworzyła odrębny organizm państwowy z własnym rządem, administracją i wojskiem. Obie republiki uzgadniały tylko politykę zagraniczną i sprawy wojskowe. Oprócz tego Dyrektoriat wspierał ZOURL finansami, żywnością, a jej wojsko - Ukraińską Armię Halicką - amunicją ${ }^{74}$.

Odbudowa URL postępowała w bardzo skomplikowanej sytuacji międzynarodowej. RSFRR aktywizowała przygotowania do wtargnięcia z północnego wschodu. Na południu - w rejonie Odessy, Mikołajewa, Chersonia - wylądował francusko-grecki desant, który do połowy stycznia 1919 r. wzrósł do 30 tys. osób. W Sewastopolu zakotwiczyła eskadra Ententy. Na północnym Kaukazie formowała się Armia Ochotnicza armia A. Denikina, która w najbliższym czasie mogła rozwinąć działania wojenne przeciw URL na południowo-wschodnim kierunku. Na zachodzie już istniał front polski: w Galicji trwała walka między wojskami ZURL i Polski. Nieprzyjazną wobec Ukrainy pozycję zajmowała Rumunia, która do tego czasu okupowała Północną Bukowinę i Besarabię. Dyskusje nad pytaniem, który front uznać za najważniejszy nie dały wyników, więc URL walczyła na wszystkich frontach i była jak w oblężonej twierdzy ${ }^{75}$. Najgroźniejsza jednak była sytuacja na wschodzie. Rewolucja w Niemczech i koniec wojny światowej kardynalnie oddziałało na politykę rosyjskich bolszewików wobec Ukrainy. Już 11 listopada 1918 r. rząd RSFRR wydał dyrektywę, która zobowiązywała Rewolucyjną Wojskową Radę Republiki w dziesięciodniowym terminie przygotować się do wojny w celu poparcia „ukraińskiego rewolucyjnego i powstańczego ruchu", a 13 listopada anulował traktat brzeski, cofając uznanie suwerenności Ukrainy. Następnego dnia, 14 listopada, W. Antonow-Owsiejenko rozpoczął ofensywę na Ukrainę. Posługiwano się powtarzającym się wszędzie schematem: tworzono rozmaite ośrodki władzy radzieckiej, którym siły zbrojne radzieckiej Rosji oraz bolszewików Ukrainy szły na pomoc. 20 listopada 1918 r. ogłoszono utworzenie w Kursku Tymczasowego Rządu Robotniczo-Chłopskiego Ukrainy na czele z G. Piatakowem; został on niezwłocznie uznany przez RSFRR. Na prośbę tego rządu rosyjska armia bol-

73 W. Serczyk, op. cit., s. 285; WEP XXX 183.

75 М. Капустянський, Похід украӥнських армій на Київ - Одесу в 1919 роиі..., t. 1, cz. I-II, s. 21-26; В. Верига, Визвольні змагання..., t. 2, s. 17-23. 
szewicka prowadziła ofensywę i zwalczała ruchy opozycyjne; uzbrojono bolszewików ukraińskich $\mathrm{w}$ sile ok. 86 tys. żołnierzy ${ }^{76}$. Niepewna była jedynie reakcja sił zbrojnych niemieckich na przekroczenie przez Rosje granicy ukraińskiej. Niemcy jednak poddali się bolszewickiej agitacji i przepuścili przez zajmowane tereny oddziały radzieckie. W dniach 19-20 grudnia $1918 \mathrm{r}$. bolszewicy osiągnęli porozumienie z Radą żołnierską wojsk niemieckich, według której niemieckie jednostki przed 24 grudnia miały otworzyć ukraińską granicę, a do 2 stycznia 1919 r. opuścić Charków i wpuścić do miasta Armię Czerwoną. Główne uderzenie rosyjskich wojsk radzieckich rozpoczęło się 12 grudnia 1918 r. 31 grudnia 1918 r. rząd URL wysłał do Moskwy notę protestacyjną żądając bezzwłocznego wycofania wojsk z Ukrainy; bez odpowiedzi. Druga nota z 3 stycznia 1919 r. również została bez odpowiedzi. Tegoż dnia radzieckie wojska weszły do Charkowa, a 14 grudnia zdobyli Czernihów. Rosyjscy bolszewicy zaprzeczali udziałowi swojej armii w działaniach wojennych przeciwko URL i "radzili" Dyrektoriatowi, aby porozumieli się $\mathrm{z}$ „całkiem niepodległym" rządem radzieckiej Ukrainy. Dyrektoriatowi nic nie pozostawało jak 16 stycznia 1919 r., w 42 dniu agresji, proklamować stan wojny z RSFRR i zawiesić wszczęte wcześniej rokowania w Moskwie ${ }^{77}$. Na front przeciwbolszewicki rząd URL w styczniu 1919 r. usiłował wysłać około 36 tys. regularnych wojsk. Przeprowadzona mobilizacja nie dała efektu. W styczniu 1919 r. z 300-tysięcznej armii powstańczej Dyrektoriatu pozostało zaledwie 40 tys. żołnierzy ${ }^{78}$. Do połowy stycznia 1919 r. Armia Czerwona zajęła duże obszary Ukrainy na lewym brzegu Dniepru. Podjęte przez rząd URL próby nawiązania kontaktu z Ententą, zwłaszcza dowództwem francuskim w Odessie w celu wspólnej akcji przeciwko rosyjskim bolszewikom, nie dały efektu. Ententa otwarcie stawiała na biały ruch i odrodzenie dawnej „wielkiej” Rosji. 31 stycznia 1919 r. ambasada USA w Londynie wysłała do Waszyngtonu kopię memorandum „Sytuacja na Ukrainie” brytyjskiego Foreign Office, w którym konkludowano: „żadnej nadziei nie można pokładać $w$ separatystycznym ruchu Petlury i jakakolwiek pomoc temu ruchowi skończy się klęską, jak to już było w końcu 1917 roku. Prawdziwym niebezpieczeństwem na Ukrainie jest tylko bolszewizm i można go zwalczyć, popierając wyłącznie rosyjską Armię Ochotniczą generała Denikina". Zachodnie demokracje były przekonane, że Dyrektoriat sam stoi zbyt blisko bolszewizmu ${ }^{79}$.

\footnotetext{
76 М. Стахів, Україна проти большевиків. Нариси з історії агресї Совєтської Росії, t. 2, Тернопіль 1993, s. 31.

77 Нариси з історії дипломатії Украӥни, s. 342-343; І. Нагаєвський, Історія Украйнської держсви двадцяятого століття, Київ 1993, s. 262-263; П. Христюк, Замітки і матеріяли до історії Української революиії 1917-1920, t. 4, Відень 1921, s. 31-40. М. Стахів, Украйна проти больщевиків, t. 2, s. 32-33.

79 Нариси з історії дипломатії України, s. 345.
} 
Po upadku Charkowa bolszewicy proklamowali 6 stycznia 1919 r. ${ }^{80}$ zmianę nazwy państwa na: Ukraińska Socjalistyczna Republika Radziecka (USRR). Już wcześniej proklamowany Tymczasowy Rząd Robotniczo-Chłopski przekształcony został 29 stycznia 1919 r. w Radę Komisarzy Ludowych USRR. Jej przewodniczącym został bułgarski komunista Christian Rakowski ${ }^{81}$. Zapowiedziano federację z RSFRR ${ }^{82}$. Na Ukrainie po raz drugi, jak w końcu 1917 r., powstały dwa organizmy państwowe, przy czym radziecka forma państwa była narzucona $\mathrm{z}$ zewnątrz.

Już w czasie formalnego stanu wojny między RSFRR i jej satelitą USSR przeciw URL w życiu państwowym URL zaszły kolejne zmiany. 23 stycznia 1919 r. w Kijowie zebrał się Kongres Pracy jako przedparlament Ukrainy. Planowano, że Dyrektoriat złoży przed nim swoje upoważnienia. Miał on liczyć 528 posłów wybranych według systemu kurialnego: 377 od chłopów, 118 od robotników i 33 od inteligencji pracującej. Prawo wyborcze przysługiwało wszystkim obywatelom URL, którzy ukończyli 21 lat bez różnicy płci, wyznania i na-

80 Charków został stolicą Ukrainy do $1934 \mathrm{r}$.

81 Christian Rakowski, pseud. H. Isarov (1873-1941), bułgarski działacz komunistyczny na Ukrainie; syn zamożnego posiadacza ziemskiego i kupca z Dobrudży; usunięty z gimnazjum za zorganizowanie straju; studiował w Genewie, ukończył medycynę w Montpellier we Francji; krótko studiował też prawo w Paryżu; pracował jako lekarz w armii rumuńskiej (1897-1900); od młodości związany z organizacjami rewolucyjnymi finansowanymi przez rodzinę; w Genewie wstąpił do rosyjskiej partii socjaldemokratycznej; aresztowany i deportowany; wyjechał do Berlina, gdzie aresztowany i deportowany, wyjechał do Francji; współpracował z Leninem i Trockim, publikował $\mathrm{w}$ ich pismach; działał $\mathrm{w}$ ruchach rewolucyjnych: rosyjskim, niemieckim, szwajcarskim, rumuńskim i ukraińskim; w Rosji carskiej pod obserwacją policji; prowadził praktykę lekarską w Paryżu; 1904 odziedziczył majątek ojca; osiadł w Konstancy i praktykował jako lekarz i prawnik; wspierał ruch rewolucyjny w Rumunii; prowadził agitację wśród zrewoltowanej załogi pancernika „Potiomkin", która uprowadziła go do Konstancy; 1907 władze rumuńskie wydały Rakowskiemu zakaz powrotu do kraju; mieszkał w Niemczech, Francji, Bułgarii, wrócił do Rumunii, aresztowany i wydalony; amnestionowany 1912; występował przeciwko wojnie (1914); lipiec 1917 - przeniósł się do Rosji i współpracował z bolszewikami w Odessie i Petersburgu; z obawy przed aresztowaniem przez Rząd Tymczasowy Kiereńskiego ukrywał się (sierpień-grudzień 1917) w Szwecji; styczeń 1918 - dokooptowany do KC SDPRR(b); członek Komitetu Wykonawczego Międzynarodówki Komunistycznej; przewodniczący Rady Komisarzy Ludowych Ukrainy radzieckiej i jednocześnie komisarz spraw zagranicznych, przewodniczący rady obrony (styczeń 1919-lipiec 1923); członek Politbiura KC Komunistycznej Partii (bolszewików) Ukrainy; od lipca 1923 odwołany z Ukrainy, na placówkach dyplomatycznych ZSRR w Wielkiej Brytanii i Francji; styczeń 1928 - odwołany ze wszystkich funkcji i jako trockista deportowany do Azji Środkowej; 1934 odciął się od Trockiego i swoich wcześniejszych poglądów; wrócił do Moskwy; przyjęty ponownie do partii; pracował w instytucie naukowym resortu zdrowia; aresztowany 1937, zmuszony do przyznania się, że był agentem brytyjskim i japońskim; otrzymał 20 lat łagru; rozstrzelany w więzieniu po ataku III Rzeszy na ZSRR; autor wielu artykułów. P. Broué, Między Trockim a Stalinem. Chrystian Rakowski - biografia polityczna, tłum B. Panek, Wrocław-Warszawa-Kraków 1999; M. J. Chodakiewicz, w: Stownik biograficzny Europy Środkowo-Wschodniej..., s. 1052-1053; W. Serczyk, op. cit., s. 272, 290, 294, 307; Leksykon historii świata: Rosja..., s. 214; zob. też L. Trocki, Zdradzona rewolucja. Czym jest ZSRR i dokąd zmierza?, tłum. A. Achmatowicz, Pruszków 1991, s. 79. 
rodowości z warunkiem przynależności do klas pracujących. Wybory do Kongresu byli dwustopniowe: gminy wiejskie wybierały elektorów odpowiednio do liczby wyborców, a ci na powiatowych zjazdach wybierali swego posła na Kongres. Podobnie wybierano posłów w kurii robotniczej. Faktycznie na Kongres przybyło ponad 400 posłów, w tym 36 z ZOURL ${ }^{83}$. Formalnie Kongres zatwierdził akt połączenia URL i ZURL. Najważniejsza była Ustawa o kształcie władzy na Ukrainie z 28 stycznia 1919 r. Ze względu na pogorszającą się sytuację wewnętrzną i zewnętrzną republiki Kongres wyraził wotum zaufania Dyrektoriatowi i powierzył mu tymczasowe pełnienie najwyższej władzy ustawodawczej do zwołania kolejnej sesji Kongresu Pracy. Do Dyrektoriatu kooptowano szóstego członka z ZURL - Eugeniusza Petruszewycza, będącego jej prezydentem. Natomiast władza wykonawcza należała do rządu - Rady Ludowych Ministrów, w czasie pomiędzy sesjami Kongresu powoływanego i odpowiedzialnego przed Dyrektoriatem. Kongres wypowiedział się przeciwko zaprowadzenia na Ukrainie dyktatury robotniczej i wypowiedział się za demokratycznym ustrojem URL. W tym celu planował przygotować ustawę dla przeprowadzenia wyborów do ukraińskiego parlamentu. Do czasu skonstruowania nowych, pochodzących z wyborów, władz rząd URL mianował swoich komisarzy, którzy w terenie powinni byli współpracować i podlegać kontroli ze strony lokalnych rad pracy. Ze względu na ofensywę wojsk czerwonych Kongres Pracy uchwalił zawieszenie obrad i wyłonił ze swego składu sześć komisij z upoważnieniami ustawodawczymi i kontrolnymi ${ }^{84}$.

Sytuacja na froncie przeciwbolszewickim pogorszyła się na tyle, że Dyrektoriat i rząd URL wyjechali (2 lutego 1919) z Kijowa do Winnicy; wkrótce trzeba się było ewakuować dalej. Armia Czerwona weszła do Kijowa 5 lutego $1919 \mathrm{r}$.

13 lutego Dyrektoriat mianował nowy, prawicowy rząd pod przezydencją Sergiusza Ostapenki. Nie miał on, zresztą jak i poprzedni, charyzmatycznych postaci. Jednak premier postanowił wzmocnić go fachowcami. 14 lutego rząd uchwalił tymczasową ustawę O porządku wnoszenia i zatwierdzenia ustaw w Ukraińskiej Republice Ludowej. Akt ten wprowadzał dwie struktury rządowe. Gabinet Ludowych Ministrów oraz Radę Ludowych Ministrów. Gabinet miał w swoim składzie premiera oraz ministrów resortowych, zaś Rada ponadto kierowników resortów. Ścieżka legislacyjna wyglądała w taki sposób, że projekty ustaw były przedkładane premierowi, a ten decydował o przedstawieniu ich Gabinetowi albo Radzie. Ustawę podpisywał premier oraz właściwy minister albo kierownik resortu. W sytuacjach nadzwyczajnych Dyrektoriat

83 В. Верига, Визвольні змагання..., t. 2, s. 34, 35; І. Мазепа, Украйна в огні й бурі революиіӥ 1917-1921, s. 84 .

84 Аиректорія, Рада Народних Міністрів Української Народної Республіки. Аистопад 1918 - листопад 1920 pp., t. 2, s. $467-468$. 
sam mógł stanowić ustawy, bez uczestnictwa Gabinetu Ministrów ${ }^{85}$. Dla ważności aktów Dyrektoriatu wymagane były podpisy wszystkich jego członków.

Okres od lutego do czerwca 1919 r. był szczególnie trudny dla URL. Prezes Dyrektoriatu W. Wynnyczenko ustąpił ze stanowiska. Desperackie próby rządu nawiązania kontakty z Ententą nie dały pozytywnych wyników. Gabinet S. Ostapenki nie wydał żadnego dokumentu programowego określającego jego działalność w sprawach polityki wewnętrznej. Doprowadziło to do jego całkowitej izolacji. Porażki na froncie nasiliły chaos w administracji państwowej. Późniejszy premier URL Izaak Mazepa zanotował: „Za rządu Ostapenki nie istniała ani władza, ani kontrola"86. Formalnie po ustąpieniu W. Wynnyczenki stanowiska prezesa nie obsadzono i tylko 9 maja specjalną uchwałą obowiązki prezesa przeniesiono na S. Petlurę, który był jednocześnie Głównym Atamanem armii URL. W skład Dyrektoriatu wchodziły wówczas cztery osoby; jak poprzednio, pełnił on rolę kolektywnej głowy państwa z kompetencjami ustawodawczymi. W maju 1919 r. rząd URL kontrolował zaledwie część Wołynia. 14 maja 1919 r. oddziały armii generała Józefa Hallera rozwinęły ofensywę na północno-zachodnim Wołyniu i zajęły Łuck z ogromnymi magazynami amunicji. Faktycznie Dyrektoriat i rząd URL utracili terytorium i z resztkami wojska schronili się na niezajętych na razie przez wojsko polskie terenach ZOURL, w Tarnopolu. Jednak już 2 czerwca Polacy zdobyli miasto i władze URL wycofały się na stację Bohdanówka nad Zbruczem. Sytuacja była krytyczna, ponieważ ze wschodu nacierały wojska bolszewickie, a z zachodu polskie. Władze państwowe i wojsko URL znaleźli się na wąskim pasie ziemi szerokości $10-20 \mathrm{~km}$. W tym krytycznym momencie S. Petlura wydał rozkaz przełamania frontu bolszewickiego. $\mathrm{W}$ rezultacie udanego manewru oddziały ukraińskie przerwały front bolszewicki i zdobyły Kamieniec Podolski, który na dłuższy czas stał się siedzibą władz państwowych URL. Ukraińską ofensywę ułatwiło podpisanie 16 czerwca z Polską zawieszenia broni, a 20 czerwca tymczasowego rozejmu, którego zresztą nie uznał rząd ZOURL i prezydent E. Petruszewycz ${ }^{87}$. „Rok 1919 był na Ukrainie czasem zupełnej anarchii. Terytorium kraju rozpadło się na wiele obszarów oddzielonych od siebie i reszty świata." - napisał Richard Pipes ${ }^{88}$ i są to słowa bardzo trafnie sumujące obraz rzeczywistości. Paraliż administracji centralnej spowodował nasilający się chaos, najgorszym przejawem którego były pogromy, zwłaszcza żydowskie, w których uczestniczyły najczęściej nieregularne oddziały wojskowe, tylko no-

85 Аиректорія, Рада Народних Міністрів Української Народної Республіки. Аистопад 1918 - листопад 1920 pp., t. 1, s. 14.

86 I. Мазепа, Україна в огні і бурі революиії 1917-1921, s. 98.

87 Б. Гудь, В. Голубко, Нелегка дорога до порозуміння. Ао питання генези українсько-польськокго військово-політичного співробітниитва 1917-1921 рр., Аьвів 1997, s. 16.

88 R. Pipes, Czerwone imperium. Powstanie Zwiazku Sowieckiego, tłum. W. Jeżewski, Warszawa 2015, s. 139. 
minalnie uznające zwierzchnictwo dowództwa armii ukraińskiej. Największy pogrom miał miejsce w lutym 1919 r. w Płoskirowie, do którego dołączyły się niektóre oddziały armii regularnej. Pogrom wstrzymali Strzelcy Siczowi pod dowództwem E. Konowalca, a jego przywódców ukarano. Oczywiście kompromitowało to administrację państwową, lecz ta była bezsilna. Rząd URL i S.Petlura nigdy nie prowadzili polityki antysemickiej. Przeciwnie, rząd przyjął ustawę o narodowościowo-personalnej autonomii i do swego składu włączył ministra do spraw żydowskich ${ }^{89}$.

Część Ukrainy znajdująca się pod rządami bolszewików otrzymała (10-14 marca 1919 w Charkowie) konstytucję ${ }^{90}$. Konstytucja była wierną kopią rosyjskiej z 1918 r., ale stanowiła, że USRR ma prawo prowadzenia własnej polityki zagranicznej, decydowania o wojnie i pokoju; z biegiem czasu rozmaite oznaki odrębności likwidowano, m.in. armię narodową ${ }^{91}$ Z inicjatywy Centralnego Komitetu Wykonawczego USRR ${ }^{92}$, w wyniku porozumienia radzieckich republik Rosji, Ukrainy, Lotwy, Litwy i Białorusi, dekretem WCKW (1 VI 1919) postanowiono zjednoczyć wszystkie siły dla wspólnej walki z kontrrewolucją i wrogami; dotyczyło to także dowództwa wojskowego ${ }^{93}$. W kwietniu 1919 r. Armia Czerwona dotarła do Zbrucza, dawnej granicy Rosji z Austro-Węgrami. 25 czerwca 1919 r. państwa Ententy upoważniły Polskę do zajęcia Galicji Wschodniej po rzekę Zbrucz ${ }^{94}$. Również w kwietniu na południu Ukrainy Armia Czerwona zdobyła Odessę, Symferopol, Sewastopol.

Natomiast druga połowa 1919 r. zapowiadała się jako koniec władzy radzieckiej w całej dawnej Rosji. „Na wiosnę 1919 r. zaplanowano przeciwko Rosji Radzieckiej kombinowaną wyprawę Kołczaka-Denikina-Judenicza." ${ }^{95} \mathrm{Od}$ wiosny z rejonu północnego Kaukazu niepowstrzymanie szły przez Ukrainę na Moskwę Siły Zbrojne Południa Rosji (SZPR) pod zwierzchnictwem gen. Antona Denikina. Stanowiły je: Armia Ochotnicza, Armia Dońska oraz wojsko Kozaków kubańskich ${ }^{96}$ i Armia Kaukaska gen. Piotra Wran-

89

90

92

В. Сергійчук, Погроми в Украйні 1914-1920. Від штуиних стереотипів до гіркої правди прихованої в радянських архівах, Київ 1998, s. 544.

История советской конституиии. Сборник документов. 1917-1957..., s. 113-118; История советской конституиии (в документах) 1917-1956..., s. 192-198. W oficjalnych dokumentach data konstytucji tak właśnie jest zapisana: 10-14 marca.

1 E. Toczek, op. cit., s. 10.

Rezolucja CKW USRR z 18 maja 1919 r.: История советской конституиии. Сборник документов. 1917-1957..., s. 118-119; История советской конституиии (в документах) 1917-1956..., s. $206-207$.

История советской конституиии. Сборник документов. 1917-1957..., s. 119; История советской конституции (в документах) 1917-1956..., s. 207-208.

W. Serczyk, op. cit., s. 286.

J. Stalin, Dzieła, t. 4, Warszawa 1951, s. 295.

Tak oto po latach oceniał sytuację Trocki, oczywiście twierdząc, że jego plan prowadzenia operacji militarnych był lepszy: „Kozacy tworzyli na tyłach Denikina potężną zasłonę. Wrośli w swą ziemię i trzymali się jej zębami i pazurami. Nasz atak postawił na nogi całą ludność kozacką. Trwoniliśmy 


\section{gla ${ }^{97}$. Na północy - z terytorium Estonii - na czele Korpusu Północnego ${ }^{98}$ ofen-}

czas i siły, pchając jednocześnie do szeregów białych wszystkich kozaków zdolnych do noszenia broni." L. Trocki, Moje życie..., s. 506.

97 Piotr Nikołajewicz Wrangel (1878-1928 Bruksela), wywodził się z rodu pochodzenia szwedzkiego; po studiach w Instytucie Górniczym w Petersburgu zaciągnął się do wojska carskiego; urlopowany z armii na 2 lata pracował jako chemik na Syberii; wrócił (1904) do służby wojskowej; 1910 ukończył Akademię Sztabu Generalnego; w czasie I wojny dowodził korpusem kawalerii; po bolszewickim zamachu stanu wyjechał na Krym i po utworzeniu (grudzień 1918) Sił Zbrojnych Południa Rosji (SZPR) (gen. A. Denikina) zzostał wyznaczony dowódcą Ochotniczej Armii Kaukaskiej; popadł $\mathrm{w}$ konflikt z Denikinem na tle odmiennych koncepcji strategicznych: Wrangel uważał, że należy dążyć do połączenia sił z Kołczakiem, zaś Denikin nakazal ruszać wprost na Moskwę; 4 kwietnia 1920 zastąpił pokonanego Denikina na stanowisku wodza SZPR; na Krymie i w południowym Taurydzie przeprowadził reformę rolną; odstąpił od hasła "niepodzielnej Rosji” i uznał niepodległość Polski oraz suwerenność Ukrainy; ustanowił federacyjne stosunki z niezależną Gruzją także walczącą z bolszewikami; nie przewidywał jednak żadnej formy samodzielności ustrojowej dla walczących wspólnie w SZPR Kozaków dońskich, kubańskich, tereckich ani astrachańskich, jak też dla Tatarów krymskich; w czasie wojny bolszewicko-polskiej w lipcu 1920 rozpoczął ofensywę i zajął Zagłębie Donieckie oraz Odessę i podjął próbę opanowania Kubania; w jesieni 1920 próbował znaleźć sojuszników $\mathrm{w}$ walce $\mathrm{z}$ bolszewikami, m.in. zawrzeć sojusz militarny z Polską, ale rząd polski nie był tym zainteresowany; po utracie ponad połowy wojska ewakuował się z wojskiem i ludnością cywilną (listopad 1920) przez Turcję do Królestwa Serbów, Chorwatów i Słoweńców; osiadł (1927) w Brukseli; działał wśród emigracji rosyjskiej; oficjalnie zmarł na gruźlicę, ale istnieje przypuszczenie, że został otruty przez służby specjalne ZSRR; pochowany w cerkwi w Belgradzie. A. Jach, w: Encyklopedia Bialych Plam, t. XVIII, s. 171-172; G. Przebinda, J. Smaga, Kto jest kim w Rosji po 1917 roku. Leksykon, Kraków 2000, s. 319-320; zob. też Leksykon historii świata: Rosja..., s. 287; Leksykon historii świata, red. A. Bartnicki. Warszawa 1998, s. 518-519; Leksykon historii powszechnej..., s. 485.

98 Krótko przed końcem wojny światowej, po trudnych rozmowach wewnątrzrosyjskich, m.in. rosyjskich monarchistów, i przedstawicieli generalicji niemieckiej stanęła umowa o tworzeniu w rejonie Pskowa rosyjskiej siły zbrojnej, której wyposażenia dostarczą Niemcy. Na tereny opanowane przez tak stworzone oddziały wkraczać miały następnie wojska niemieckie dla "zapewnienia porządku”. Werbunek do przyszłego Korpusu rozpoczęto - przy niemieckiej komendanturze - w październiku 1918 r. w rejonie Psków-Dyneburg. Pierwotna jego nazwa to Pskowski Samodzielny Korpus Ochotniczy. Na stronę Korpusu przeszedł od bolszewików Stanisław Bułak-Bałachowicz. Korpus Ochotniczy pod dowództwem gen. Aleksego Rodzianko ruszył do natarcia na Piotrogród 13 maja 1919 r. Główne natarcie wspomagane było z północy słabiutkimi ruchami białej jednostki karelskiej oraz brytyjskiej, bez trudu powstrzymanymi przez czerwonych. Poprzedzona sukcesami grupy Bułaka-Bałachowicza dywizja estońska zdobyła Psków (25 maja 1919) i mogło się zdawać, że Piotrogród jest do wzięcia. 11 czerwca przez lornetki żołnierzy Korpusu widoczne były przedmieścia dawnej stolicy i pozycje obrońców. Przed decydującym o zdobyciu miasta natarciem dokonane zostały ważne - zdawało się - roszady natury politycznej. $\mathrm{Z}$ udziałem aktywnie operujących na Morzu Bałtyckim Brytyjczyków, po konsultacji z Kołczakiem, Wielkorządcą Rosyjskim, przewidziano powołanie rządu regionalnego; zdecydowano, że gen. Rodzianko pozostanie na stanowisku dowódcy Armii Północno-Zachodniej (w jaką przekształcił się Korpus Północny), a gen. Judenicz obejmie dowództwo sił rosyjskich w całym rejonie północno-zachodnim. Wydawał się Brytyjczykom być bardziej elastyczny w sprawie uznania niepodległości państw bałtyckich niż Kołczak, a specjaliści wojskowi misji brytyjskiej wskazywali, że zdobycie Piotrogrodu możliwe jest tylko z pomocą Łotwy i Estonii, a nie przeciw nim. Jak wiadomo, z Kołczakiem w tej sprawie w ogóle rozmawiać się nie dało, ale i co do Judenicza twórcy „rządu” się całkowicie pomylili. Ani Kołczak, ani Judenicz nie zgodzili się na podpisanie przygotowanej proklamacji uznania niepodległości Łotwy i Estonii. Toteż ani Łotwa, ani Estonia nie udzieliły pomocy Judeniczowi. Atak na Piotrogród zakończył się klęską i rozbiciem Armii Północno-Zachodniej; gen. Rodzianko odpłynął (24 listopada 1919) na statku brytyjskim. Po przekroczeniu granicy estońskiej rozbite 
sywę rozpoczął Judenicz ${ }^{99}$ i zdawało się, że nic nie uratuje dla czerwonych Piotrogrodu ${ }^{100}$. Od wschodu, za Uralu atakował Kołczak ${ }^{101}$. Poważnym zagrożeniem dla obu stron były duże siły atamana Nestora Machny ${ }^{102}$. Armia Czer-

jednostki białych zostały rozbrojone, co było ceną za wstrzymanie ofensywy Armii Czerwonej, która i tak zajęła rejon Narwy. R. Wojna, W ogniu rosyjskiej wojny wewnętrznej 1918-1920, Warszawa 1975, s. 199; zob. też A. Lityński, Rok 1917 i Estonii droga do pierwszej niepodległości. W setna rocznice rosyjskiej rewolucji, [w:] Księga jubileuszowa Profesora Adama Jamroza, WP UwB [w druku].

99 Nikołaj N. Judenicz (1862 w Moskwie - 1933 Cannes), uczestnik wojny rosyjsko japońskiej, od 1907 generał, od 1915 dowódca Armii Kaukaskiej oraz (III-IV 1917) Frontu Kaukaskiego; 1918 wyjechał do Finlandii, a stamtąd przybył do Estonii. Od 1920 na emigracji. Leksykon. Historia świata. Rosja..., s. 119; Leksykon historii powszechnej..., s. 195; WEP XIII s. 52.

100 Trocki twierdzi, że ,zdaniem Lenina, nie pozostawało nic innego, jak tylko oddać Piotrogród i skrócić front" i że to Trocki przy pomocy Stalina (!) wyperswadowali taką myśl Leninowi. L. Trocki, Moje życie..., s. 471 .

101 Aleksandr Wasiljewicz Kołczak (1873-1920), pochodził z Tatarów krymskich, ale urodził się koło Petersburga, ukończył Korpus Kadetów; badacz polarny oraz syberyjski, autor poświęconych im prac; w czasie wojny rosyjsko-japońskiej ranny w obronie Portu Artura; w czasie I wojny światowej dowodził marynarką wojenną na Bałtyku i Morzu Czarnym; od 1917 admirał; od 18 listopada 1918 Wielkorządca Rosji; zorganizował armię, która zajęła znaczną część Syberii i Ural i dotarła (marzec 1919) Wołgi; zamiast koordynacji działań z Denikinem K. chciał pierwszy zająć Moskwę i poniósł klęskę od Armii Czerwonej; 6 stycznia 1920 zrzekł się godności na rzecz Denikina; oddał się w ręce żołnierzy Korpusu Czechosłowackiego, a ci wydali go bolszewikom; rozstrzelany 7 lutego 1920 w Irkucku. WEP XIV, s. 160; Leksykon historii świata: Rosja..., s. 134; G. Przebinda, J. Smaga, Kto jest kim w Rosji po 1917 r. ..., s. 139; Leksykon historii powszechnej..., s. 211.

102 Nestor Machno (1889-1934 Paryż), anarchista, przywódca partyzantki ludowej na Ukrainie; pochodził z biednej rodziny chłopskiej ze wsi Hulaj Pole koło Jekaterynosławia; w młodości wstąpił do kółka anarchistycznego i za udział w zamachu na oficera policji skazany na dożywotnie więzienie, gdzie na Butyrkach spotkał się z Piotrem Arszynowem, filozofem i taktykiem anarchizmu i dużo się w tym zakresie nauczył; zwolniony w wyniku amnestii po rewolucji lutowej 1917 wrócił do Hulaj Pola i tam stworzył zbrojną bandę, która grabiła okoliczne dwory i rozdawała dobra biednym chłopom; podczas okupacji Ukrainy przez państwa centralne ukrywał się, a następnie wyjechał do Moskwy gdzie spotkał się m.in. z Leninem oraz Piotrem Kropotkinem - głównym teoretykiem anarchizmu komunistycznego; w jesieni 1918 wrócił w rodzinne strony i podjął działania zbrojne przeciwko wojskom austriackim oraz siłom Skoropadśkiego, a następnie przeciwko Dyrektoriatowi URL; na dużym obszarze opanowanym przez siły Machny realizował anarchistyczny model niezależnego państewka opartego na komunach wiejskich, okresowo także w Jekaterynosławiu i Aleksanddrowsku; zwalczał antysemityzm; jego hasło to „,jesteśmy za bolszewikami, ale przeciw komunistom"; miał ogromny talent i instynkt dowódcy dużych formacji wojskowo-partyzanckich, w niekorzystnym położeniu jego chłopscy żołnierze rozpraszali się wśród ludności wiejskiej, by na wezwanie ugrupować się i uderzyć niespodziewanie z ogromną siłą; jego pomysłem było zastosowanie taczanki - zaprzęgu konnego z zamontowanym ciężkim karabinem maszynowym; miał ogromny posłuch i autorytet wśród podwładnych; w 1919 współpracował z Armią Czerwoną przeciwko siłom Denikinowi, któremu zadał druzgocące ciosy; okresowo walczył z lokalnymi władzami bolszewickimi; jego siły przyjęte w lutym 1919 do Armii Czerwonej szacować można nawet na blisko 100 tys. ludzi; odmówił, gdy bolszewicy próbowali wysłać go na front polski; występował przeciwko kontyngentom żywnościowym władzy radzieckiej; jego podkomendni dopuszczali się okrucieństw i grabieży; w czerwcu 1919 został wyjęty spod prawa i formalnie pozbawiony dowództwa, ale nie miało to praktycznego znaczenia, gdyż jego ludzie nadal go słuchali; kazał zabić dwóch agentów Czeki, którzy prawdopodobnie mieli go zamordować; w jesieni 1920 zgodził się na ponowną współpracę z Armią Czerwoną przeciwko armii gen. Wrangla; po pokonaniu Wrangla bolszewicy zaatakowali i pochwycili sztab oraz dużą liczbę żołnierzy Machny i w większości ich wymordowali; Machno wymknął się z obławy i zbiegł i przez Rumunię, Polskę, Niemcy; dotarł 
wona była bliska całkowitego załamania ${ }^{103}$. Już w końcu czerwca Siły Zbrojne Południa Rosji wkroczyły do Charkowa i Carycyna (później Stalingrad, obecnie Wołgograd); Kijów oraz Odessa padły tego samego dnia (23 sierpnia 1919), kilka dni później Połtawa; padł Kursk (20 września 1919), później Czernihów, Woroneż zdobyty przez Kozaków dońskich, a 13 października 1919 r. Armia Ochotnicza zdobyła Orzeł i natychmiast ruszyła w pościg za cofającymi się jednostkami Armii Czerwonej. W najwyższym stopniu zagrożona była przemysłowa Tuła, a „utrata Tuły byłaby dla nas katastrofą, gdyż znaczyłaby stratę najważniejszej fabryki karabinów i amunicji. [...], utrata której byłaby groźniejsza w skutkach od utraty Moskwy." 104 Dla bolszewików nie byłoby ratunku, ale - jak wiadomo - wszyscy biali generałowie szli z hasłami odbudowy dawnej niepodzielnej, nieuszczuplonej Rosji, bez koncesji na rzecz narodów. Wszak dlatego Piłsudski nie podjął współpracy wojskowej z Denikinem i zadeklarował wstrzymanie działań zbrojnych na czas walk czerwonych z Denikinem. Program społeczny oraz ustrojowy niesiony przez wojska Denikina był zdecydowanie kontrrewolucyjny. Zaślepienie Denikina wydaje się być absolutnie skrajne, a podobnie skrajny był terror stosowany na zajętych przez niego terenach Ukrainy.

\section{Kryzys republiki i zwrot ku Polsce}

Zaprzestanie działań wojennych armii URL przeciwko wojskom polskim w czerwcu 1919 r. umożliwiło rządowi URL skoncentrowanie siły na froncie przeciwbolszewickim. Doszło do kolejnej zmiany rządu URL, tym razem na lewicowy pod premierostwem Borysa Martosa. Do 25 czerwca wszystkie ministerstwa przeniosły się do Kamieńca Podolskiego i zaczęły pracę. Przyjęty (25 czerwca 1919) na posiedzeniu rządu projekt ustawy o tymczasowych statutach Gabinetu i Rady Ludowych Ministrów, o trybie zatwierdzania i publikacji ustaw i uchwał i o skasowaniu poprzednich ustaw w tej sprawie wzmacniał pozycję rządu ponieważ ten uzyskiwał kompetencje ustawodawcze i inne administracyjne, które nie leżały $\mathrm{w}$ kompetencjach Dyrektoriatu ${ }^{105}$. Projekt nie wszedł jednak w życie i relacje pomiędzy Dyrektoriatem i rządem nadal nie były uregulowane.

do Paryża, gdzie pracował jako prosty robotnik, rozpił się, zmarł w biedzie na gruźlicę. W. Roszkowski, w: Stownik biograficzny Europy Środkowo-Wschodniej..., s. 766-767; W. Serczyk, op. cit., s. 275; G. Przebinda, J. Smaga, Kto jest kim w Rosji, s. 174-175; WEP XVI 369; Leksykon historii świata: Rosja, s. 161; Leksykon historii powszechnej..., s. 254; Leksykon historii świata, red. A. Bartnicki..., s. 253.

103 G. Swain, Wojna domowa w Rosji, tłum. Z. Simbierowicz, Warszawa 2007, s. 148, passim.

104 L. Trocki, Moje życie..., s. 506.

105 Аиректорія, Рада Народних Міністрів Украӥнської Народної Республіки. Аистопад 1918 - листопад 1920 pp., t. 1, s. 21. 
Częsta zmiana linii frontu, kurczenie się terytorium republiki, zmiany w lokacji instytucji centralnych fatalnie skutkowały na gospodarkę, spowodowały prawie całkowitą ruinę systemu fiskalnego. Budżet URL stracił dochody, a faktycznie w 1919 r. nie istniał. Kryzys finansowy burzył państwowość ukraińską o wiele bardziej niż klęski na froncie. Pieniędzy brakowało na wojsko, urzędników państwowych, system oświaty i ochrony zdrowia. Głównym źródłem dochodów państwa stała się emisja pieniędzy. Ale na Ukrainie zabrakło niezbędnych dla druku banknotów urządzeń technicznych. Ich część emitowano w Niemczech, skąd samolotami przewożono do Kamieńca Podolskiego.

W celu stabilizacji władzy w państwie, w czerwcu 1919 r. grupa polityków ukraińskich z Podola w memorandum złożonym Dyrektoriatowi żądała jego zreformowania i przekształcenia $\mathrm{w}$ jednoosobową prezydenturę $\mathrm{z}$ tymczasową konstytucją, a także skonstruowania gabinetu ministrów na zasadzie fachowości, a nie przynależności partyjnej, skasowania uchwały o radach pracy i rozwiązania kwestii agrarnej w drodze wykupu ziemi przez chłopów. W tym czasie nasiliła się konfrontacja między rządem ZOURL i URL na płaszczyźnie polityki socjalnej. Przywódcy URL uważali program ZOURL za konserwatywny, prawicowy, ci z ZOURL zaś zarzucali URL zbytni socjalny radykalizm szkodliwy dla państwa. Oprócz tego E. Petruszewycz kategorycznie odrzucał kontakty URL z Polską. W rezultacie 4 lipca 1919 r. został usunięty ze składu Dyrektoriatu, który od tego czasu liczył tylko trzy osoby - S. Petlura, A. Makarenko i F. Szwec.

Pogorszenie się sytuacji militarnej bolszewików na frontach $\mathrm{z}$ armiami białymi, zwłaszcza z Denikinem, dało szansę S. Petlurze wznowienia działań wojennych. Po przejściu 16-17 lipca Armii Halickiej na wschodni brzeg Zbrucza sytuacja na ukraińsko-radzieckiemu froncie istotnie zmieniła się. Na pomoc S. Petlurze przyszła dobrze zorganizowana siła. Szacuje się, że w tym czasie w bojowym składzie miała 39 tys. szeregowców i 1200 oficerów, czyli razem 40200 osób. Łącznie zjednoczone wojska liczyły do 84 tys. ludzi, a nadto około 20 tys. w oddziałach powstańczych ${ }^{106}$. Od połowy lipca do połowy listopada 1919 r. Kamieniec Podolski stał się siedzibą dwóch rządów - URL i ZOURL. Chcąc uzyskać sympatię prawicowych polityków galicyjskich, a także zapewnić sobie poparcie ze strony dowództwa Armii Halickiej, S. Petlura dokonał korekty $\mathrm{w}$ rządzie, uzupełniając go osobami o umiarkowanych poglądach. 12 sierpnia 1919 r. rząd URL wystąpił z kolejną deklaracją, w której określał swoją politykę, a także zmiany w systemie politycznym republiki. W deklaracji stwierdzał, że będzie „opierać się na całym narodzie i przyciągać do państwowej pracy wszystkie warstwy społeczeństwa, którym są drogie osiągnięcia

106 О. М. Завальнюк, С.В. Олійник., Українська Галицька армія на Поділлі (липень 1919 - травень 1920 рр., Камянець-Подільський 2013, s. 64-65. 
ukraińskiej rewolucji i niepodległość naszej rewolucji"107. W związku z powyższym oświadczał, że ma zamiar przygotować projekt ustaw o wyborach do parlamentu i o utworzeniu sformowanych na podstawie demokratycznych wyborów organów samorządu terytorialnego. Doszło także do zmiany premiera. Od 26 sierpnia 1919 r. urząd ten objął Izaak Mazepa reprezentujący umiarkowaną lewicę

Latem 1919 r. zmienił się klimat polityczny na Ukrainie. Ukraińskie chłopstwo, odczuwszy na sobie politykę „wojennego komunizmu” rosyjskich bolszewików, podniosło powstanie. Nie akceptowało ono także reakcyjnej polityki Denikina, który zaczął zajmować południowe obszary posuwając się na lewobrzeżnej Ukrainie i wypierając stamtąd bolszewików. W tej sytuacji S. Petlura zdecydował się na przeprowadzenie ofensywy przeciwko wojskom radzieckim w celu zdobycia Kijowa. Zjednoczona ukraińska armia na początku sierpnia 1919 r. liczyła razem z powstańczymi oddziałami, które podporządkowywały się dowództwu armii, ok. 100 tys. osób. Ofensywa rozwijała się pomyślnie. 30 sierpnia 1919 r. Ukraińcy zdobyli Kijów, lecz już następnego dnia wkroczyły tam oddziały armii A. Denikina ${ }^{108}$. Nie mając precyzyjnych rozkazów od sztabu Armii URL odnośnie stanowiska wobec niej, generał A. Krauz jako dowódca grupy wojsk ukraińskich w Kijowie rozpoczął pertraktacje, wynikiem czego stało się wycofanie wojsk ukraińskich ze stolicy. Iluzja o możliwym porozumieniu z generałem A. Denikinem, na co liczył rząd URL, ostatecznie upadła. W 1925 r., będąc już na emigracji w Paryżu, S. Petlura trafnie zauważył, że „między carską Rosją i współczesną komunistyczną dla nas nie ma różnicy, bo obie one przedstawiają tylko różne formy moskiewskiej despotii i imperiali$z^{\prime \prime 109}$. Po stracie Kijowa i kategorycznej odmowie A. Denikina prowadzenia rokowań z dowództwem Armii URL (dopuszczał rozmowy tylko z przedstawicielami Armii Halickiej) 15 września 1919 r. na wspólnej naradzie Dyrektoriatu i rządu URL z udziałem E. Petruszewycza omawiano perspektywy wszczęcia działań wojennych przeciwko rosyjskim wojskom białogwardyjskim. Ukraińskie wojska ustępowały uzbrojeniem i amunicją, miały słabszy oficerski korpus ${ }^{110}$. Jednak białogwardziści zmuszeni byli wyodrębnić część sił do walki $\mathrm{z}$ armią Machno. Po tym jak 21 września ukraińska strona przechwyciła rozkaz

107 I. Мазепа, Украӥна в огні і бурі революиії..., s. 241.

108 І. Крип'якевич, Б. Гнатевич, 3. Стефранів, Історія Украӥнського війська (від княжих иасів до 20- $х$ років ХХ ст.), Аьвів 1992, s. 559-560; М. Омелянович-Павленко, Спогади українського командарма, s. 192-199; В. Чабанівський, Вступ украйнського війська до Києва 31 серпня 1919 року, [w]: За Аержавність. Матеріяли до історії війська українського, 3б. 8, Варшава 1938, s. 152-154.

109 С. Петлюра, Розпочинаючи видання, [w]: Петлюра С. В., Статті, s. 311.

110 W przeddzień ukraińsko-białogwardyjskiego konfliktu na południowym kierunku frontu przeciw 7500 ukraińskich bagnetów i szabli skoncentrowano ponad 10 tys. rosyjskich sił białych, bez uwzględnienia rozlokowanych w miastach Południowej Ukrainy i na Krymie załóg, gdzie przebywało do 5 tys. bagnetów. 
A. Denikina rozpoczęcia działań wojennych przeciwko Armii URL, na wspólnej naradzie naddnieprzańskich i galicyjskich przywódców, w obecności S. Petlury i E. Petruszewicza, zaakceptowano wspólną deklarację o ogłoszeniu 24 września stanu wojny z Denikinem. Właśnie wówczas z Polską zostało podpisane przedłużenie rozejmu i określona linia demarkacyjna na zachodzie wzdłuż rzeki Zbrucz, a dalej od miasta Wołoczysk w kierunku na Sławutę - Ołewsk - Mozyrz. Miało to zabezpieczyć tyły ukraińskiej armii dla otwarcia działań przeciw wojskom białogwardyjskim ${ }^{111}$. W ostatnich dniach września 1919 r. na prawobrzeżnej Ukrainie rozpoczęły się zacięte walki Armii URL z siłami Denikina. W końcu października oddziały armii ukraińskiej zaczęły tracić wartość bojową.

Przyczyną tego było wyczerpanie się zasobów wojennych, a zwłaszcza epidemia tyfusu, która nabrała drastycznych rozmiarów. Stan ogólny pogarszał się z powodu bezradności aparatu państwowego URL. Współredaktor bliskiej rządowi „Gazety Robotniczej” Panas Fedenko pisał: "Dużą przeszkodą dla ukraińskiego ruchu wyzwoleńczego w 1919 r. był brak politycznie wykształconej i profesjonalnej ukraińskiej inteligencji. Zabrakło ukraińskich fachowców dla państwowego aparatu, brakowało ukraińskich politycznych przywódców dla roboty w masach"112. Faktycznie, pod koniec października 1919 r. rząd kontrolował tylko kilka powiatów na Podolu. URL została całkiem odcięta od światu blokadą, którą zaprowadziła Ententa, traktująca URL jako państwo sprzymierzone z państwami centralnymi oraz wspierające Denikina. Nawet zakupione przez rząd URL w Amerykańskim Czerwonym Krzyżu leki i inny sprzęt medyczny nie zostały przepuszczone na Ukrainę. Petlura próbował wpłynąć na złagodzenie pozycji Ententy przez swojego dawnego przyjaciela, znanego francuskiego dziennikarza Jeana Pélissier'a. W liście z Kamieńca Podolskiego do Paryża datowanym 29 października 1919 r. pisał: „Nie dostaliśmy żadnej pomocy; ani amunicji, ani sprzętu sanitarnego. Nic! ... Ileż to tragicznych chwil przyszło nam przeżyć przez całkowite opuszczenie nas! Często zdarzało się, że naszym żołnierzom brakowało pocisków! I wtedy musieli kłaść swoje głowy $\mathrm{w}$ ataku na bagnety z bolszewikami... Trzy czwarte naszej armii bez obuwia i odzieży... Nie mamy leków; tyfus dziesiątkuje szeregi naszej armii, wielu zranionych umiera ponieważ nie mamy medykamentów i bielizny. A państwa Ententy, które proklamują szlachetne zasady, zabraniają Czerwonemu Krzyżowi przybyć do nas! Umieramy, a Ententa jak Piłat umywa ręce i nam nic więcej nie pozostaje jak zawołać: morituri te salutant!"113. Tragiczna sytuacja,

111 Zob. М. Ковальчук, Невідома війна 1919 року. Украйнсько-білогвардійське збройне протистояння, Київ 2006, s. 106-121.

112 О. Аоценко, Аітопис Української революиії, t. 2, ks. 4, Аьвів 1924, s. 255.

113 С. Петлюра, Аист до франиузького публіииста Жана Пелісье, [w:] Петлюра С. В. Статті, s. 186$-187$. 
przede wszystkim armii, spowodowała nasilenie się wśród dowództwa przekonania o niezbędności zawieszenia broni. Najmocniej takie nastroje panowały w Armii Halickiej, która najbardziej ucierpiała od epidemii tyfusu. 6 listopada jej dowódca generał Myron Tarnawski zgodził się na podpisanie $\mathrm{z}$ armią A. Denikina umowy o zawieszeniu broni. Tydzień później zaakceptował ją E. Petruszewycz. Znaczyło to ostateczny rozłam pomiędzy władzami naczelnymi URL. W nocy z 15 na 16 listopada E. Petruszewycz wraz z najbliższym otoczeniem wyjechał przez Rumunię do Wiednia, gdzie stanął na czele emigracyjnego rządu ZURL. W tym samym czasie (15 listopada) doszło do zasadniczych zmian $\mathrm{w}$ systemie zarządzania państwem. Na wspólnym posiedzeniu Dyrektoriatu i rządu przyjęto uchwałę o wysłaniu za granicę dwóch członków Dyrektoriatu - A. Makarenki i F. Szweca - z zadaniem reprezentowania na emigracji interesów URL i kontrolowania działalności wszystkich jej instytucji i urzędników tam się znajdujących, a także celem podpisywania umów politycznych i wojskowych. W czasie ich nieobecności naczelne kierowanie sprawami URL zostało przekazane prezesowi Dyrektoriatu S. Petlurze, który „w imieniu Dyrektoriatu zatwierdza wszystkie ustawy i uchwały, przyjęte przez Radę Ludowych Ministrów". Na wypadek jego śmierci naczelny zarząd sprawami państwowymi republiki i jej siłami zbrojnymi przechodził na pozostałych członków Dyrektoriatu aż do wyłonienia się parlamentu ukraińskiego ${ }^{114}$. Uchwała prawnie legitymizowała jednoosobową władzę S. Petlury. Tego samego dnia została uchwalona tajna instrukcja dla przewodniczącego warszawskiej misji dyplomatycznej Andrzeja Liwickiego, w której strona ukraińska godziła się na przebieg ukraińsko-polskiej granicy wzdłuż linii Bartelemy'ego z lutego 1919 r. przewidującej pozostawienie w Polsce większej części Galicji Wschodniej ze Lwowem i borysławskim zagłębiem naftowym.

Ze względu na niebezpieczeństwo, które zawisło ze strony wojsk A. Denikina nad Kamieńcem Podolskim, jeszcze 13 listopada zarządzono ewakuacje aparatu państwowego do Płoskirowa. Petlura wysłał telegram do polskiego dowództwa, w którym proponował Polakom zajęcie Kamieńca Podolskiego. W mieście miała pozostać część aparatu urzędowego na czele z ministrem Iwanem Ohijenką, którego mianowano głównym pełnomocnikiem rządu. Miał on obowiązek nadzorować drukarnię papierów wartościowych i archiwa. Na zajętych przez polskie oddziały terenach na życzenie S. Petlury miała pozostawać cywilna administracja ukraińska, a także mienie państwowe URL. 16 listopada z Kamieńca Podolskiego wyszły oddziały ukraińskie i tegoż dnia weszły tam oddziały polskie ${ }^{115}$. W Płoskirowie rząd nie zatrzymał się długo, ponieważ na-

114 Аиректорія, Рада Народних Міністрів Украӥнської Народної Республіки. Аистопад 1918 - листопад 1920 рр., t. 1, s. 27; t. 2, s. 599; С. Петлюра, Статті, листи, документи, t. III, Київ 1999, s. $142-143$.

115 J. J. Bruski, Petlurowcy. Centrum Państwowe Ukraińskiej Republiki Ludowej na wychodźstwie (1919-1924), Kraków 2002, s. 95; В. А. Савченко, Авенадиать войн за Украину, Харьков 2006, s. 284-285. 
cierały oddziały armii A. Denikina. Aparat rządowy z nielicznym wojskiem ruszył dalej na północ $\mathrm{w}$ kierunku Starokonstantynowa, gdzie pod osłoną wojsk polskich spodziewano się przegrupować armię. Ukraińska administracja $\mathrm{w}$ terenie była zupełnie zrujnowana. $\mathrm{Z}$ wielkim trudem dotarli do Lubara i Czartoryi w południowej części Wołynia. Z 12 członków rządu razem z S. Petlurą pozostało tylko 5 ministrów i ok. 30 urzędników. Wszyscy pracownicy urzędów otrzymali zezwolenie wyjazdu do Polski. Za granicą znajdowali się najważniejsi ministrowie. Najwyższe władze pozostające jeszcze na terytorium Ukrainy zostały zredukowane do minimum. Ostatecznie zdezorganizował centrum państwowe bunt kilku atamanów 2-3 grudnia 1919 r. przeciwko rządowi. 4 grudnia w Nowej Czartoryi w obecności S. Petlury odbyło się ostatnie posiedzenie rządu i dowódców wojskowych, na którym zapadła decyzja rozwiązania regularnego frontu i rozpoczęcia partyzanckiej formy walki z rosyjskimi najeźdźcami. Petlura mianował dowódcą armii URL generała Mychajła Omelanowicza Pawłenkę, a 5 grudnia wraz z kilkoma najbliższymi współpracownikami opuścił siedzibę rządu i wyjechał do Warszawy, aby sfinalizować już głęboko zaawansowane pertraktacje o przyszłym sojuszu polsko-ukraińskim znanym w literaturze jak sojusz Piłsudski - Petlura. Przed swoim wyjazdem wraz z pozostałymi ministrami wydał odezwę do narodu w której oznajmił, że rząd nie zawiesza swojej działalności, a przechodzi do innych metod walki i będzie ją prowadził do zwycięstwa ${ }^{116}$.

Jesienią 1919 r. zreorganizowana i przegrupowana Armia Czerwona ruszyła (10 października 1919) do kontrofensywy. To wówczas ujawnił się talent Siemiona Budionnego ${ }^{117}$. SZPR rozpoczęły $\mathrm{w}$ nieładzie odwrót na południe;

116 С. В. Петлюра, Cmammi, s. 190-192.

117 Siemion Michajłowicz Budionny (1883-1973), podoficer w armii carskiej, uczestnik wojny rosyjsko-japońskiej; w czasie I wojny światowej czterokrotnie odznaczany za odwagę; od lutego 1918 dowódca jednego z czerwonych oddziałów partyzanckich; w partii bolszewickiej od 1919; organizator czerwonej kawalerii, pomysłodawca zastosowania tzw. taczanek, tj. zaprzęgów konnych wyposażonych w ciężkie karabiny maszynowe; dowódca 1 Armii Konnej, która dzięki mobilności odegrała ważną rolę w walkach z siłami Denikina, a potem w wojnie 1920 z Polską; armia Budionnego wsławiła się okrucieństwami i grabieżami, co m.in. opisał I. Babel w Armii Konnej; obok sławy bojowej przyrosła do Konarmii sława bandycka, którą armia ta przerosła wszystkich; 1922 odznaczony trzykrotnie orderem Czerwonego Sztandaru; 1924-1937 dowódca kawalerii Armii Czerwonej; 1935 jeden z pięciu pierwszych marszałków ZSRR; w okresie wielkiego terroru stalinowskiego (1935-1938) wykonawca poleceń Stalina; trzykrotny bohater Związku Radzieckiego; 6 Orderów Lenina; przypisano mu wszystkie zasługi innych dowódców kawalerii, stał się postacią dekoracyjną oficjalnych imprez, m.in. to on na białym koniu poprowadził defiladę na Placu Czerwonym w rocznicę rewolucji w dramatycznych dniach 1941; 1939-1941 zastępca ludowego komisarza obrony; 1941-1945 członek kwatery głównej; 1938-1952 członek KC WKP(b); od 1938 członek Prezydium Rady Najwyższej ZSRR; pochowany pod murem kremlowskim. W. Bieszanow, Kadry decyduja o wszystkim, tłum. A. Palacz, Warszawa 2009, s. 154 i passim; G. Przebinda, J. Smaga, Kto jest kim w Rosji..., s. 42-43; Leksykon historii świata: Rosja..., s. 48; E. Mawdsley, Wojna..., s. 276-277; R. Wojna, W ogniu..., s. 179; B. Potyrała, R. Fudali, Siły zbrojne Związku Radzieckiego 1945-1991, Warszawa 2009, s. 132, passim; E. Radziński, Stalin, Warszawa 1996, s. 421, 512. 
wycofywały się 720 km aż przekroczyły Don. Radziecka kontrofensywa była już tylko jednym ciągiem sukcesów militarnych. W grudniu 1919 r. czerwoni zajęli zarówno Charków, jak i Kijów, w lutym 1920 r. Odessę; tylko na Krymie utrzymały się pozostałości SZPR. Po dymisji generała A. Denikina dowództwo nad Zbrojnymi Siłami Południa Rosji objął generał P. Wrangel, który był skłonny do większego kompromisu z URL. Wszak było już za późno.

W grudniu 1919 r., na konferencji partyjnej Rosyjskiej Komunistycznej Partii (bolszewików) w Moskwie powołano centrum dla spraw Ukrainy, a tuż za postępującą Armią Czerwoną na Ukrainie proklamowano Ogólnoukraiński Komitet Rewolucyjny, na czele z Ch. Rakowskim i Dymitrem Manuilskim ${ }^{118}$, przekształcony później (II 1920) w Radę Komisarzy Ludowych Ukrainy ${ }^{119}$. Przewodniczącym Rady Komisarzy Ludowych Ukrainy radzieckiej był nadal Christian Rakowski, rewolucjonista europejski o bardzo ciekawym życiorysie; umiał on zająć postawę szanowania dążeń narodowych proletariatu i federalizacji ${ }^{120}$, dawał szanse na spokojne ułożenie stosunków na pogrążonej w chaosie i zbolałej Ukrainie. Myli się w tym miejscu R. Pipes, który twierdzi, że Rakowski reprezentował centralistyczny i antynarodowy charakter czerwonego rządu ukraińskiego ${ }^{121}$. Rakowski w postawie federalistycznej i ogólnie łagodnym kursie

118 Dmytro (Dymitr) Manuilski (1883-1959), urodzony na Wołyniu, studia rozpoczął na Uniw. Petersburskim; 1903 wstąpił do SDPRR(b); uczestnik rewolucji 1905; skazany 1906 na 5 lat zesłania zbiegł do Kijowa; wyjechał 1907 do Paryża, gdzie ukończył prawo na Sorbonie; potem okresowo nielegalnie przebywał w Moskwie i Petersburgu, następnie znowu za granicą; wrócił do Rosji w 1917; brał udział w bolszewickim zamachu stanu; 1918 wysłany przez KC partii bolszewickiej na Ukrainę $\mathrm{w}$ celu zorganizowania tam ruchu bolszewickiego; przez pewien czas zbliżony do frakcji federalistycznej $\mathrm{w} \mathrm{KP}(\mathrm{b}) \mathrm{U}$ opowiadającej się za federacyjnym równoprawnym związkiem z Rosją radziecką; 1919-1920 wchodził w skład Wszechukraińskiego Komitetu Rewolucyjnego; uczestniczył w rozmowach pokojowych z Polską w Rydze; długoletni członek Biura Politycznego KP(b)U i członek jego prezydium; 1920-1922 ludowy komisarz rolnictwa USRR; 1921 I sekretarz KC KP(b)U; 1923-1953 w KC WKP(b); zdecydowanie popierał Stalina w jego walce o władzę; od 1924 członek prezydium Komitetu Wykonawczego Międzynarodówki Komunistycznej; 1928-1943 sekretarz Komitetu Wykonawczego Międzynarodówki Komunistycznej; jeden z głównych wykonawców polityki Stalina w Kominternie, w tym czystek; członek Akademii Nauk USRR; 1944 wicepremier i ludowy komisarz spraw zagranicznych USRR; przewodniczył ukraińskim delegacjom na konferencjach międzynarodowych po II wojnie światowej, delegat USRR w ONZ; m.in. publicznie atakował emigrację ukraińską, a także organizował nagonkę na czołowych twórców ukraińskich w kraju; przeszedł na emeryturę. B. Berdychowska, w: Słownik biograficzny Europy Środkowo-Wschodniej..., s. 790; А. Сурайко, А. З. Мануильский - революционер, дипломат, ученый, Киев 1983; Leksykon historii świata: Rosja, s. 164; Leksykon historii powszechnej..., s. 262; W. Serczyk, op. cit., passim.

119 История советской конституиии (в документах) 1917-1956.., s. 212-214; zob. W. Lenin, List do robotników i chłopów Ukrainy..., s. 41; toż w innych tłumaczeniach idem, Dzieła..., s. 641 i passim; idem, Dzieła..., s. 864 i passim; W. Serczyk, op. cit., s. 278-279; R. Pipes, Czerwone imperium..., s. 150.

120 Zob. na ten temat zwłaszcza P. Broué, Między Trockim a Stalinem. Chrystian Rakowski-biografia polityczna, tłum. B. Panek, Wrocław-Warszawa-Kraków 1999, s. 130, 162-163, 169, passim; W. Serczyk, op. cit., s. 295, passim; M. J. Chodakiewicz, w: Stownik biograficzny Europy Środkowo-Wschodniej..., s. 1053.

121 R. Pipes, Czerwone imperium..., s. 150. 
narodowym znajdował $\mathrm{w}$ tym momencie silne wsparcie Lenina. Obaj przeszli wyraźnie zmianę w stosunku do wcześniej zajmowanej postawy i działań, kiedy Ukraina była głownie terenem eksploatacji dla zaspokajania potrzeb centrum Rosji i armii; była to nowa polityka ${ }^{122}$.

W Warszawie Petlura podjął ostatnią próbę ratowania Ukrainy wiążąc się z Polską: najpierw podpisał z rządem polskim kolejno dwie umowy rozejmowe (16 czerwca oraz 1 września 1919), następnie umowę polityczną (21 kwietnia 1920) i wreszcie konwencję wojskową (25 kwietnia 1920). Polska uznawała Dyrektoriat za legalny rząd niepodległej Ukrainy, zaś strony ustalały granicę państwową „na północ od rzeki Dniestr wzdłuż rzeki Zbrucz, a następnie wzdłuż byłej granicy między Austro-Węgrami a Rosją [...]"123. Jak wiadomo, umowa wywołała ostrą krytykę dużej części znanych polityków ukraińskich obarczających S. Petlurę zarzutem zdrady stanu. Petlura wówczas alternatywy nie miał. Można zgodzić się z B. Skaradzińskim, że uznanie przynależności Galicji ze Lwowem do Polski „oznaczała jednak rezygnację z głównej bazy społecznej dla wskrzeszenia wolnej Ukrainy. Komu, jak komy, ale Ukraińcom musiało to już być - praktycznie - wiadome, że ich główne, państwowotwórcze siły społeczne lokalizują się wokół Lwowa, Stanisławowa, Równego i Tarnopola. Na wielkiej zaś Ukrainie trzeba było dopiero w mozole zabiegać, z nie wiadomo jak szybkim skutkiem, aby uformowały się tam takie siły"124. Jeszcze raz, już ostatni wówczas, Kijów został oswobodzony od bolszewików. Wojna bolszewicko-polska nie będzie tutaj przedmiotem omówienia, ponieważ - można przypuszczać - jest znana. Należy jednak zauważyć, że wojna ta była zupełnie ostatnią wówczas próbą wyrwania bolszewikom europejskiego fragmentu dawnej Rosji. Koniec tej wojny był końcem wojny domowej w europejskiej części dawnej Rosji. Ukraińską Republikę Rad strona polska uznała już w październiku 1920 r. podczas zawierania umowy o preliminariach pokojowych i o rozejmie na $21 \mathrm{dni}^{125}$. Strona polska wypowiedziała układ państwowy z Ukraińską Republiką Ludową i zerwała umowy wojskowe i polityczne ${ }^{126}$. Po zakończeniu wojny bol-

122 Zob. W. Lenin, List do robotników i chłopów Ukrainy..., s. 43-44; toż w innych tłumaczeniach: idem, Dzieła.., s. 643 i passim; idem, Dzieła..., s. 865-866 i passim; P. Broué, Między Trockim a Stalinem. Chrystian Rakowski..., s. 130, 350, passim.

123 М. Стахів, Третя Совєтська республіка в Україні. Нариси з історії третьої воєнної інвазії Советської Росії в Украӥну і розвиток окупаційної системи в иасі: листопад 1919 - листопад 1924, Нью-Йорк 1968, s. 106.

124 B. Skaradziński, Polskie lata 1919-1920, t. 2: Sąd Boży, Warszawa 1993, s. 22.

125 Zob. J. Kukułka, Traktaty sąsiedzkie Polski odrodzonej, Wrocław-Warszawa-Kraków 1998, s. 42.

126 Zob. J. Kumaniecki, Po traktacie ryskim. Stosunki polsko-radzieckie 1921-1923, Warszawa 1971, s. 36; Z. Karpus, Traktat ryski a polscy sojusznicy w okres wojny polsko-bolszewickiej 1920 r., [w:] Traktat ryski 1921 r. po 75 latach. Studia, red. M. Wojciechowski, Toruń 1998, s. 236. Wprawdzie przedstawiciel URL Oleksiuk wraz z polską delegacją przez Gdańsk i Libawę dotarł do Rygi, ale nie uczestniczył $\mathrm{w}$ rokowaniach przy stole obrad. Strona polska nie była w stanie wymusić na delegacji sowieckiej zmiany jej stanowiska w kwestii ukraińskiej i jedynym reprezentantem społeczności ukraińskiej był 
szewicko-polskiej w rozmowach pokojowych z Polską chodziło o przyszłość i granice nie Rosji sensu stricto, ale Ukrainy i Białorusi, przy czym Federacja Rosyjska oraz Ukraina występowały w rokowaniach samodzielnie i negocjowały układ na rzecz Białorusi. Białoruś w rokowaniach nie uczestniczyła ${ }^{127}$ i nie można twierdzić - jak czynią to niektóre źródła rosyjskie ${ }^{128}$ - iż Białoruś była reprezentowana przez Rosję. Białoruś nie była stroną traktatu. Obie układające się strony (Rosja i Ukraina z jednej i Polska z drugiej) wyraźnie jednak „uznają niepodległość Ukrainy i Białorusi” (art. II traktatu ryskiego, Dz.U. RP z 1921 r. Nr 49, poz. 300) ${ }^{129}$. Polska była też pierwszym krajem, który nawiązał stosunki dyplomatyczne $\mathrm{z}$ radziecką Ukrainą. Te szczegóły wskazują na zawiłość problemów, splot strony formalnej oraz faktycznej, krzyżowanie się polityki i prawa.

W restytuowanej na krótko w 1920 r. URL doszło do ważnych z prawnego punktu widzenia zmian $\mathrm{w}$ ustroju naczelnych władz państwowych. Jeszcze będąc na terenie Ukrainy rząd URL 11 listopada 1920 r. przyjął ustawę o tymczasowym najwyższym zarządzie i trybie ustawodawstwa w Ukraińskiej Republice Ludowej. Przewidywała ona, że do czasu uchwalenia konstytucji naczelna władza przechodzi w ręce Dyrektoriatu, Państwowej Ludowej Rady i Rady Ludowych Ministrów. Dyrektoriat w osobie jego prezesa był upoważniony do zatwierdzania uchwalonych przez Państwową Ludową Radę ustaw, nominacji i odwołań z urzędów, dokonanych przez Radę Ludowych Ministrów; ten sam tryb przewidziano $w$ odniesieniu do umów międzynarodowych. Ustawa przewidywała, że w przypadku niemożności pełnienia swych obowiązków przez prezesa Dyrektoriatu jego funkcję przechodzą na zastępcę przewodniczącego Państwowej Ludowej Rady, a do momentu jej zwołania - na kolegium złożone z premiera, kierownika Sądu Najwyższego, i osobę reprezentującą wszystkie partie polityczne. Tegoż dnia została uchwalona ustawa o Państwowej Ludowej Radzie Ukraińskiej Republiki Ludowej, która powoływała do życia przedparlament - Państwową Ludową Radę o kompetencjach ustawodawczych. Miała ona działać do zwołania parlamentu ${ }^{130}$.

przedstawiciel Ukrainy bolszewickiej (zob. Z. Karpus, Traktat ryski.., s. 238). Rząd URL wyznaczył swoją delegację, z S. Szełuchinem na czele, na konferencję pokojową. Delegacja ta przybyła do Rygi 3 października 1920 r., jeszcze przed podpisaniem preliminariów pokojowych i rozejmu, ale nie rozmawiano z nią. W sumie w Rydze przebywały trzy ukraińskie delegacje. Zob. E. Wiszka, Ukraińska Republika Ludowa wobec rozmów pokojowych i traktatu ryskiego 1921 r., [w:] Traktat ryski..., s. 280,286 , passim.

127 Zob. m.in. O. Łatyszonek, Białoruskie elity polityczne wobec traktatu ryskiego, [w:] Traktat ryski..., s. 289 i n.

128 История отечественного государства и права.., s. 155.

129 Zob. też J. Kukułka, op. cit., s. 42 i 136.

130 Аиректорія, Рада Народних Міністрів Украӥнської Народної Республіки. Аистопад 1918 - листопад 1920 pp., t. 2, s. 676-684. 
W końcu listopada 1920 r. terytorium URL w całości okupowała Armia Czerwona. Władze URL udały się na emigrację. Właśnie ostatnie uchwalone akty stały się podstawą prawną funkcjonowania Centrum Państwowego URL na wychodźstwie i formalnie zapewniły ciągłość państwowości ukraińskiej. W dniu 22 sierpnia 1991 r. Centrum Państwowe URL złożyło swoje upoważnienia na ręce prezydenta niepodległej Ukrainy Leonida Krawczuka tym podkreślając, że współczesne państwo ukraińskie jest prawnym następcą URL ${ }^{131}$.

\section{Uwagi końcowe}

Walka o suwerenność państwa ukraińskiego zakończyła się wówczas porażką. Złożyły się na to różne przyczyny, tak wewnętrzne, jak i zewnętrzne. Nie bez znaczenia było przerwanie ciągłości tradycji państwowotwórczej na Ukrainie, jej trwałe ulokowanie $\mathrm{w}$ imperium carów spowodowało mocne zintegrowanie $\mathrm{z}$ Rosją. $\mathrm{W}$ rezultacie po upadku samodzierżawia Ukraińcy rozpoczęli budowę państwa, które miało być sfederowane z Rosją, łudząc się, że nowe demokratyczne państwo rosyjskie zapewni im szeroko określoną autonomię. Jednak wydarzenia potoczyły się tak, że przekonały elity ukraińskie o niemożności zrealizowania planów narodowych w związku federacyjnym z Rosją, ponieważ ta nadal zachowała tradycje imperialne. $W$ rezultacie przystępując do budowy narodowej państwowości przywódcy ukraińscy spotkali się z wieloma trudnościami: brakiem wykształconej kadry urzędniczej, korpusu oficerskiego dla tworzącego się wojska, znikomym doświadczeniem w budowie machiny państwowej. Trzeba wziąć pod uwagę, że próba budowy państwa miała miejsce w czasach rewolucji, kiedy nastąpił zupełny upadek tradycyjnych wartości, m.in. takich jak szacunek do władzy i administracji państwowej. Błędy popełnione przez władze ukraińskie rzutowały na sytuację $\mathrm{w}$ kraju, powodując chaos i anarchię. Bardzo niesprzyjająca była sytuacja międzynarodowa.

\section{Bibliografia}

\section{Bibliografia alfabetem tacińskim}

W. Bieszanow, Kadry decyduja o wszystkim, tłum. A. Palacz, Warszawa 2009.

P. Broué, Między Trockim a Stalinem. Chrystian Rakowski - biografia polityczna, tłum. B. Panek, Wrocław-Warszawa-Kraków 1999.

J. Bruski J. J., Petlurowcy. Centrum Państwowe Ukraińskiej Republiki Ludowej na wychodźstwie (1919-1924), Kraków 2002.

131 Аержавний Центр Української Народньої Республіки в екзилі: Статті і матеріяли, Філядельфія, Київ, Вашінгтон 1993, s. 204-205. 
R. Conquest, Wielki terror, tłum. W. Jeżewski, Warszawa 1997.

Encyklopedia Biatych Plam, t. XVIII.

M. Filar, W stużbie utopii. 73 lata radzieckiego prawa karnego, Torun 1992.

J. Hrycak, Historia Ukrainy 1772-1999. Narodziny nowoczesnego narodu, tłum. K. Kotyńska, Lublin 2000.

Z. Karpus, Traktat ryski a polscy sojusznicy w okres wojny polsko-bolszewickiej 1920 r., [w:] Traktat ryski 1921 r. po 75 latach. Studia, red. M. Wojciechowski, Torun 1998.

J. Kukułka, Traktaty sąsiedzkie Polski odrodzonej, Wrocław-Warszawa-Kraków 1998.

J. Kumaniecki, Po traktacie ryskim. Stosunki polsko-radzieckie 1921-1923, Warszawa 1971.

Leksykon historii powszechnej 1900-1945, red. S. Sierpowski i S. Żerka, Poznań 1996.

Leksykon historii świata, red. A. Bartnicki, Warszawa 1998.

Leksykon historii świata: Rosja, red. W. Sienkiewicz, Warszawa 2001.

W. Lenin, Dzieła wybrane, t. 2, Warszawa 1949.

W. Lenin, Dzieła wszystkie, t. 40, Warszawa 1988.

W. Lenin, Dzieła wszystkie, t. 35. Warszawa 1988.

W. Lenin, Dzieła wybrane, t. 3, Warszawa 1978.

A. Lityński, Rewolucji rosyjskiej rok pierwszy. Wybrane zagadnienia prawa karnego, [w:] Nil nisi veritas. Księga dedykowana Profesorowi Jackowi Matuszewskiemu, red. M. Głuszak, D. Wiśniewska-Jóźwiak, Łódź 2016.

A. Lityński, Rok 1917 i Estonii droga do pierwszej niepodległości. W setna rocznice rosyjskiej rewolucji, w: Księga jubileuszowa Profesora Adama Jamroza, WP UwB [w druku].

O. Łatyszonek, Białoruskie elity polityczne wobec traktatu ryskiego, [w:] Traktat ryski 1921 r. po 75 latach. Studia, red. M. Wojciechowski, Torun 1998.

E. Mawdsley, Wojna domowa w Rosji 1917-1920, tłum. M. Popławska, Warszawa 2010.

R. Pipes, Czerwone imperium. Powstanie Związu Sowieckiego, tłum. W. Jeżewski, Warszawa 2015.

R. Pipes, Rosja bolszewików, tłum. W. Jeżewski, Warszawa 2005.

B. Potyrała, R. Fudali, Siły zbrojne Zwiazku Radzieckiego 1945-1991, Warszawa 2009.

G. Przebinda, J. Smaga, Kto jest kim w Rosji po 1917 roku. Leksykon, Kraków 2000.

E. Radziński, Stalin, Warszawa 1996.

J. Rohoziński, Bawełna, samowary i Sartowie. Muzutmańskie okrainy carskiej Rosji 1795-1916, Warszawa 2014.

W. Serczyk, Historia Ukrainy, wyd. 4, Wrocław 2009.

B. Skaradziński, Polskie lata 1919-1920, t. 2: Sąd Boży, Warszawa 1993.

Słownik biograficzny Europy Środkowo-Wschodniej, red. W. Roszkowski i J. Kofman, Warszawa 2004.

J. Stalin, Dzieła, t. 4, Warszawa 1951. 
G. Swain, Wojna domowa w Rosji, tłum. Z. Simbierowicz, Warszawa 2007.

E. Toczek, wstęp do: Konstytucja Ukrainy uchwalona na piatej sesji Rady Najwyższej Ukrainy 28 czerwca 1996 r., wstęp i tłumaczenie E. Toczek, Warszawa 1999.

L. Trocki, Moje życie. Próba autobiografii, autoryzowany przekład z rosyjskiego J. Barski i S. Łukomski, Warszawa 1930 [reprint Warszawa 1990].

L. Trocki, Zdradzona rewolucja. Czym jest ZSRR i dokąd zmierza?, tłum A. Achmatowicz, Pruszków 1991.

Wielka Encyklopedia Powszechna PWN [WEP], Warszawa.

E. Wiszka, Ukraińska Republika Ludowa wobec rozmów pokojowych i traktatu ryskiego 1921 r., [w:] Traktat ryski 1921 r. po 75 latach. Studia, red. M. Wojciechowski, Toruń 1998.

R. Wojna, W ogniu rosyjskiej wojny wewnętrznej 1918-1920, Warszawa 1975.

\section{Bibliografia cyrylicą ukraińską i rosyjską}

В. Андрієвський, 3 минулого. Від гетьмана до Аиректорї̈, t. 2, Берлін 1923.

Т. Андрусяк, Правові основи украйнської гетьманської держави 1918 року, [w]: Останній гетьман. Ювілейний збірник пам'яті Павла Скоропадського 1873-1945, Київ 1993.

Е. Бош, Год борьбъг, Киев 1990.

Великий жовтень і громадянська війна на Украӥні. Енииклопедичний довідник, Київ 1987.

В. Верига, Визвольні змагання в Украӥні 1914-1923, t. 1, Аьвів 1998, s. 288.

В. Винниченко, Відродження нацї: (Історія украйнської революиї, марець 1917 р. грудень 1919 р.). У 3 m. (Репринт. відтворення вид. 1920 р.), t. 3, Київ 1990.

О. Гавриленко, І. Аогвиненко, Гетьмансъкий переворот 29 квітня 1918 р.: причини та наслідки, [w]: Актуальні проблеми юридичної науки в дослідженнях вчених: науково-практичний збірник, nr 3, Київ 2000.

Гражданская война и военная интервениия в СССР. Энииклопедия. Гл. реА. Хромов С. С., Москва 1983.

В. Гриневич, А. Гриневич, Р. Колісник, Історія Украӥнського війська 1917-1995, Аьвів 1996.

М. Грушевський, Украӥна і Росія. Переговори в справі нового ладу (липень - серпень 1917 р.), [w]: Хто такі украйнці і чого вони хочуть?, Київ 1991.

Б. Гуль, В. Голубко, Нелегка дорога до порозуміння. Ао питання генези українсько-польськокго військово-політичного співробітництва 1917-1921 рр.,

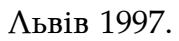

Аержавний Центр Украӥнської Народньої Республіки в екзилі: Статті і матеріяли, Філядельфія, Київ, Вашінгтон 1993.

Аеятели СССР и революиионного движения в России. Энииклопедический словарь Гранат, Москва 1989. 
Аипломатический словарь. Главная редакция А. А. Громыко, А. Г. Ковалев, Севостьянов П. П. и др., t. 1, Москва 1985.

Аиректорія, Рада Народних Міністрів Украйнської Народної Республіки. Аистопад 1918 - листопад 1920 рр.: Аок. і матеріали. У 2-х помах, 3-х иастинах, t. 1, t. 2, Київ 2006.

А. Аорошенко, Мої спомини про недавне минуле (1914-1920), Київ 2007.

О. Аоценко, Аітопис Української револющї, t. 2, ks. 4, Аьвів 1924.

О. Завальнюк, С.В. Олійник, Українська Галищька армія на Поділлі (липень 1919 травень 1920 рр., Камянець-Подільський 2013.

Из киевских воспоминаний А. А. Гольденвейзера, [w]: Архив русской революиии, t. 6, Москва 1991.

История отечественного государства и права, ч. 1-2, ред. О. И. Чистяков, Москва 2006.

История советской конституиии. Сборник документов. 1917-1957, Издательство Академии Наук СССР, Москва 1957.

Історія держсави і права Украйни, Академічний курс, t. 1-2, ред. В. Й. Тацій, А. Й. Порожин, Київ 2000.

Історія Украӥнської РСР: У 8 m., t. 5, Київ 1977.

М. Капустянський, Похід украӥнських армій на Київ - Одесу в 1919 році. (Короткий воєнно-історичний огляд), t. 1, 2, Мюнхен 1946.

М. Ковальчук, Невідома війна 1919 року. Украйнсько-білогвардійське збройне протистояння, Київ 2006.

Коновалець, Причинки до історії Украӥнської революиї, Прага 1928.

Конституиійні акти Украӥни 1917-1920. Невідомі конституиї Украйни, Київ 1992.

I. Крип'якевич, Б. Гнатевич, 3. Стефанів, Історія Украйнського війська (від княжих часів до 20-х років ХХ ст.), Аьвів 1992.

В. Кульчицький, М. Настюк, Б. Тищик, 3 історї украйнської держсавності, Аьвів 1992.

М. Аитвин, К. Науменко, Історія ЗУНР, Аьвів 1996.

В. Аободаєв, Революиійна стихія. Вільнокозацький рух в Украйні 1917-1918 рр., Київ 2010.

О. Аупандін, Аержавний сенат Украӥнськоїдержави 1918, [w]: Енииклопедія історії України: у 10 т. Редкол.: В. А. Смолій (голова) та ін., t. 2, Київ 2004.

I. Мазепа, Украӥна в огні й бурі революиї̈ 1917-1921, Київ 2003.

Я. Малик, Михайло Грушевський: незбитий шлях. Нариси життя та діяльності, Аьвів 2016.

Мирні переговори між Украйнською Аержавою та РСФР 1918 р. Протоколи і стенограми пленарних засіданъ. Збірник документів і матеріалів, Київ, НьюЙорк, Філадельфія 1999.

О. Мироненко, Аержавна варта, [w:] Мала енциклопедія етнодержавознавства, Київ 1996. 
І. Нагаєвський, Історія Украӥнської держави двадиятого століття, Київ 1993.

Нариси з історії дипломатії Украйни. Під ред. В. А. Смолія, Київ 2001.

М. Омелянович-Павленко, Спогади украӥнського командарма, Київ 2002.

Н. Полонська-Василенко, Історія Украйни, t. 2, Київ 1992.

О. Реєнт, Павло Скоропадський, Київ 2003.

В. Савченко, Авенадиать войн за Украину, Харьков 2006.

Свод основныхх государственных законов, Санкт-Петербург 1906, t. 1, сz. 1.

В. Сергійчук, Погроми в Україні 1914-1920. Від штучних стереотипів до гіркої правди прихованої в радянських архівах, Київ 1998.

С. Петлюра, Статmі, листи, документи, t. III, Київ 1999.

С. Симон Петлюра. Статті, Київ 1993.

В. Сідак, Національні спецслужби в період Української революцї 1917-1921 рр. (невідомі сторінки історії), Київ 1998.

П. Скоропадський, Спогади. Кінець 1917 - грудень 1918, Київ, Філадельфія 1995.

В. Солдатенко, Украӥнська революиія. Історичний нарис, Київ 1999.

М. Стахів, Третя Совєтська республіка в Украйні. Нариси з історії третьої воєнної інвазї Советської Росї в Україну і розвиток окупачійної системи в часі: листопад 1919 - листопад 1924, Нью-Йорк 1968.

М. Стахів, Украӥна проти большевиків. Нариси з історіӥ агресї̈ Совєтської Росії, t. 2, Тернопіль 1993.

$\Lambda$. Сурайко, А. З. Мануильский - революционер, дипломат, ученый, Киев 1983.

Ю. Тютюнник, Револючійна стихія. Зимовий похід 1919-20 рр., Аьвів 2004.

П. Христюк, Замітки і матеріяли до історії української революиї, t. 2, t. 4, Відень 1921.

В. Чабанівський, Вступ украйнського війська до Києва 31 серпня 1919 року, [w:] За Аержавність. Матеріяли до історії війська українського, 36. 8, Варшава 1938.

М. Шкільник, Украйна у боротьбі за Аержавність в 1917-1921 роках: Спомини і роздуми, Торонто 1971. 